\title{
What's Left Standing? FECA Citizen Suits and the Battle for Judicial Review
}

\author{
Kimberly N. Brown*
}

\section{INTRODUCTION}

It has long been argued that the prevailing standard for ensuring that courts adjudicate "Cases or Controversies" within the meaning of Article III of the Constitution ${ }^{1}$ is as flawed as it is fundamental. Applied most prominently in Lujan v. Defenders of Wildlife, ${ }^{2}$ the reigning test for standing to bring suit in federal court turns foremost on whether plaintiffs have suffered a particularized injury. ${ }^{3}$ It reflects the belief that courts are constrained to hearing citizens' individualized complaints, and that so-called "generalized grievances" shared by the populace are not constitutionally cognizable even if Congress explicitly granted standing to vindicate them. Lujan consequently invalidated an explicit statutory grant of standing ${ }^{4}$ to generic "citizens" on Article III grounds. "Vindicating the public interest," Justice Scalia wrote, "is the function of Congress and the Chief Executive." 6

Like the statute at issue in Lujan, the Federal Election Commission Act $(\text { FECA })^{7}$ is relatively unusual legislation because Congress did not

* Associate Professor of Law, University of Oklahoma College of Law. The author wishes to thank Sandra Ahn, John Beckerman, Joe Birkenstock, Lyn Entzeroth, Steve Gensler, Michele Gilman, Katheleen Guzman, Leslie Kelleher, Peter Krug, Edith Marshall, Harry Schwirck, Murray Tabb, Peter Tague, and Chris Brooks Whitman for comments on prior drafts of this Article. The Campaign Legal Center in Washington, D.C., provided valuable research assistance.

1. See U.S. CONST. art. III, $\S 2$ (stating that judicial power extends to certain types of cases and controversies).

2. 504 U.S. 555 (1992).

3. Id. at 560; see also Friends of the Earth, Inc. v. Laidlaw Envtl. Servs. (TOC), Inc., 528 U.S. 167, 181 (2000) (articulating standard and citing Lujan).

4. Endangered Species Act of 1973, 16 U.S.C. § 1540(g)(1) (2000).

5. See Lujan, 504 U.S. at 580 (Kennedy, J., concurring) ("The Court's holding that there is an outer limit to the power of Congress to confer rights of action is a direct and necessary consequence of the case and controversy limitations found in Article III."); see also Cass R. Sunstein, What's Standing After Lujan? Of Citizen Suits, "Injuries," and Article III, 91 MicH. L. REV. 163, 165 (1992) (citing Lujan as prompting "invalidation of an explicit congressional grant of standing to 'citizens"').

6. Lujan, 504 U.S. at 576.

7. Federal Election Campaign Act of 1971, 2 U.S.C. $\S \S 431-456$ (2000); see also infra note 
confine its enforcement to the Federal Election Commission (FEC or Commission), but included a provision enabling a private person to sue the FEC in federal court to compel enforcement of the law against a third party. ${ }^{8}$ The Supreme Court sustained the express reach of the FECA's citizen-suit provision in FEC v. Akins, ${ }^{9}$ which, in the words of Cass R. Sunstein, "is by far the most important pronouncement on the general issue of standing to obtain information ... [because] the Court appears to have held that any citizen has standing to sue under FECA." 10

Despite the ostensible scope of Akins, the question of whether any party has standing to sue the FEC under the FECA's citizen-suit provision continues to be relitigated. By relying on Lujan and its progeny, the FEC has repeatedly disavowed federal courts' jurisdiction to hear challenges to its preinvestigation dismissals of administrative complaints, not only defying the Supreme Court's pronouncement in Akins, but effectively seeking immunity from such judicial review.

This Article discusses standing to sue the FEC with two principal objectives. First, it attempts to frame the doctrinal inconsistencies between Lujan and Akins that have given rise to ongoing FECA standing litigation and concludes that the Supreme Court should acknowledge its repudiation of Lujan in cases seeking election-related information. Second, it explores the question whether courts may be statutorily required to consider citizen challenges to FEC enforcement actions as a matter of justiciability theory in the first instance, and concludes that courts should turn to the oft-overlooked Akins decision in lieu of Lujan in reviewing suits brought under citizen-suit statutes generally. ${ }^{11}$

69 (summarizing the FECA's main provisions).

8. See id. $\S 437 \mathrm{~g}(\mathrm{a})(8)$ (stating that an aggrieved party may file a petition if the FEC dismisses a complaint or fails to act on a complaint within the stated time period); see also Chamber of Commerce of the U.S. v. FEC, 69 F.3d 600, 603 (D.C. Cir. 1995) (characterizing statute as "unusual in that it permits a private party to challenge the FEC's decision not to enforce").

9. See 524 U.S. 11, 19-26 (1998) (holding that voters have standing to bring suit against the FEC for not bringing an enforcement action when they were unable to obtain information the FECA allegedly required be made public).

10. Cass R. Sunstein, Informational Regulation and Informational Standing: Akins and Beyond, 147 U. PA. L. REV. 613, 616 (1999) (citing Akins). Professor Sunstein remarked in 1999 that, "[r]emarkably, the emerging law governing standing to obtain information has yet to receive academic attention." Id. This statement remains accurate today.

11. Interestingly, in Massachusetts v. EPA, 127 S. Ct. 1438 (2007), a 5-4 majority of the Supreme Court recently found that the Commonwealth of Massachusetts had standing to sue the EPA to prompt a rulemaking to address global warming. Writing for the majority, Justice Stevens appeared to adopt an Akins-like theory of justiciability in a generalized grievance context. See id. at 1456 (quoting Akins). Chief Justice Roberts vigorously dissented and was joined by Justice Scalia, the author of the plurality decision in Lujan. See id. at 1464 (Roberts, J., dissenting) (quoting Lujan). Although the majority opinion is most notable for its apparent endowment of "special solicitude" to States in Article III standing analysis, Justice Stevens's reliance on Akins for the proposition that the fact "[t]hat the[] climate-change risks are 'widely-shared' does not minimize 
Part II reviews Akins and highlights its subtle but dramatic departures from the premises of Lujan. Upholding Congress's power to define injury in the FECA itself, the Akins Court largely dispensed with the causation and redressability requirements but failed to expressly negate conflicting aspects of Lujan. This fundamental inconsistency between Akins and Lujan has enabled relitigation of Akins itself in cases brought against the FEC.

Part III develops the theoretical underpinnings of the Akins's viewpoint that, although there must be limits on the power of Congress to define the scope of Article III standing, the case-or-controversy requirement should be interpreted as empowering Congress to legislate standing in some measure to spur executive enforcement activity. This Part considers standing under the FECA's citizen-suit provision in particular as a mechanism for enforcement of the federal campaign and election laws, and concludes that Congress's use of such power seems reasonable and circumscribed.

Part IV attempts to reconcile Lujan and Akins and their competing theoretical bases. Lujan does not faithfully remain the cohesive force in public law in any event. Rather than uniformly tamping down on attempts to vindicate generalized grievances, Supreme Court and lowercourt decisions reflect a recognition that the nature of administrative decision making necessarily provokes merits adjudication of less-thanindividualized challenges to Executive Branch activity. Courts should therefore resist the FEC's invitation to revert to a strict Lujan application of injury-in-fact. This Article proposes that courts apply Akins as creating per se standing in FECA cases seeking information, and consider its expansion to cases involving FECA-like citizen-suit statutes to the degree that the applicable substantive law of agency review already affords substantial deference on the merits. The result of this more objective standing inquiry would be litigation for the sake of shedding light on government conduct - a readily defensible democratic goal.

\section{The Standing Problem: "LUJAN V. AKINS"}

The prevailing test for Article III standing, applied in Lujan, has long been the subject of ardent critique. Although numerous scholars have

Massachusetts' interest in the outcome of this litigation" raises questions as to the future of standing doctrine in public law cases implicating so-called generalized grievances. Id. at 1455, 1456 (majority opinion) (quoting Akins, 524 U.S. at 24). 
proposed substitute standing tests, few have carefully examined the Supreme Court's own reworking of Lujan in the Akins case. ${ }^{12}$

Both Lujan v. Defenders of Wildlife and FEC v. Akins were brought under express statutory provisions authorizing suit to challenge agency inaction. Although the Supreme Court purported to apply the identical standard for Article III standing in both, it reached precisely opposite results. This Part concludes that although Akins shifted the injury-in-fact paradigm from the facts relating to plaintiff to the statutory creation of injury, its inherent analytical conflict with Lujan has enabled the FEC to challenge anyone's standing to sue it under the FECA. As a result, Akins has been relitigated repeatedly, and whether Akins controls any plaintiff's standing has been called into question. Were courts to properly recognize that Akins and Lujan are not entirely reconcilable, redundant standing litigation under the FECA's citizen-suit provision would cease.

\section{A. The Prevailing Injury-in-Fact Test}

\section{The Case-or-Controversy Requirement Encapsulated}

Standing jurisprudence contains two strands: Article III standing to sue, which enforces the Constitution's case-or-controversy requirement, ${ }^{13}$ and prudential standing, which embodies "judicially selfimposed limits on the exercise of federal jurisdiction." $" 14$ The constitutional limitation on standing, unlike the prudential one, cannot be waived by parties or Congress. ${ }^{15}$ Although the ban on "generalized grievances" originated as a prudential, or judge-made, limitation on standing, ${ }^{16}$ the Supreme Court has not consistently characterized the

12. See Sunstein, supra note 10 , at 616 (stating that, "[r]emarkably, the emerging law governing standing to obtain information has yet to receive academic attention,"- a statement that largely applies today). But see William W. Buzbee, Standing and the Statutory Universe, 11 DuKE ENVTL. L. \& POL'Y F. 247, 262-63 (2001) (discussing the retreat from Lujan in Akins); Gene R. Nichol, The Impossibility of Lujan's Project, 11 DuKE ENVTL. L. \& POL'Y F. 193, 197-98 (2001) (discussing standing analysis in Akins and Lujan).

13. See U.S. CONST. art. III, $\S 2$ (discussing federal court jurisdiction).

14. Allen v. Wright, 468 U.S. 737, 751 (1984). Although the Court has not exhaustively defined the prudential dimensions of the standing doctrine, it has explained that prudential standing encompasses three elements: (1) "the general prohibition on a litigant's raising another person's legal rights," (2) "the rule barring adjudication of generalized grievances more appropriately addressed in the representative branches," and (3) "the requirement that a plaintiff"s complaint fall within the zone of interests protected by the law invoked." Id.

15. See Gladstone, Realtors v. Vill. of Bellwood, 441 U.S. 91, 100 (1979) (observing that, although Congress may legislatively override prudential standing limits, it may not abrogate Article III minima).

16. See Warth v. Seldin, 422 U.S. 490, 490-91 (1975) (declaring that bar on citizen and 
generalized grievance restriction as such; in Lujan, the plurality construed it as part-and-parcel of the case-or-controversy requirement, ${ }^{17}$ a nuance that has erupted in confusion post-Akins. ${ }^{18}$

Article III itself does not attempt to define "Case" or "Controversy" or provide any guidelines as to what sorts of disputes are appropriately resolved through the judicial process. As the Supreme Court has observed, "an executive inquiry can bear the name 'case' . . . and a legislative dispute can bear the name "controversy." 19 According to James Madison's explanation at the Constitutional Convention, the language limits judicial review "to cases of a Judiciary Nature." 20 Because "the Constitution's central mechanism of separation of powers depends largely upon common understanding of what activities are appropriate to legislatures, to executives, and to courts, ${ }^{21}$ by restricting the availability of judicial review, standing promotes separation of powers. Of course, whether something is "of a Judiciary Nature" or "appropriate" for judicial review begs the question of whether a dispute is justiciable under Article III. Translating the case-or-controversy requirement into a single workable standard of justiciability has thus been notoriously difficult for the Supreme Court.

Historically, the Court analogized Article III standing to the common law by looking to whether the defendant's actions harmed a legal interest recognized at common law. ${ }^{22}$ Because the modern citizenry's relationship with the federal government and its administrative apparatus has no corollary under the common law system, ${ }^{23}$ this method had inherent limitations. The Supreme Court moved in the 1960s and early 1970s toward the current standard by looking to whether the plaintiff has

taxpayer suits was "prudential”).

17. See ERWIN CHEMERINSKy, FEDERAL JURISDICTION 94 (4th ed. 2003) (discussing Lujan holding).

18. See FEC v. Akins, 524 U.S. 11, 23 (1998) ("Whether styled as a constitutional or prudential limit on standing, the Court has sometimes determined that where large numbers of Americans suffer alike, the political process, rather than the judicial process, may provide the more appropriate remedy for a widely shared grievance." (citing cases)).

19. Lujan v. Defenders of Wildlife, 504 U.S. 555, 559 (1992).

20. Gene R. Nichol, Jr., Injury and the Disintegration of Article III, 74 CAL. L. REV. 1915, 1919 (1986) (quoting 2 THE RECORDS OF THE FEDERAL CONVENTION OF 1787, at 430 (Max Ferrand ed., rev. ed. 1966)).

21. Lujan, 504 U.S. at 559-60.

22. Chemerinsky, supra note 17, at 68-69 (citing Tenn. Elec. Power Co. v. Tenn. Valley Auth., 306 U.S. 118, 137-38 (1939)); Nichol, supra note 20, at 1920 (citing Joint Anti-Fascist Refugee Comm. v. McGrath, 341 U.S. 123, 151-53 (1951) (Frankfurter, J., concurring)).

23. See Nichol, supra note 20, at 1920-21 (noting that the "[g]overnment owes substantial duties and obligations to its citizenry that have no clear counterparts in the common law system" and that "[1]iberalized judicial review of administrative decisionmaking also led to a fatal collision with the purely private rights model"). 
a particular stake in the outcome of the litigation, regardless of the nature of the abstract claim. ${ }^{24}$ Justice Brennan explained in Baker v. Carr that "a personal stake in the outcome of the controversy . . . assure[s] that concrete adverseness which sharpens the presentation of issues upon which the court so largely depends for illumination of difficult constitutional questions." ${ }^{25}$ Whether a federal judge's authority is at its essence limited to resolving purely private disputes akin to those at common law remains a hotly disputed question that has shaped the Supreme Court's justiciability jurisprudence ever since.

Although the first iterations of what is now known as the "injury-infact" standard expanded plaintiffs' access to the federal courts by recognizing injuries well beyond the economic harm that was the cornerstone of the common law system, ${ }^{26}$ under Chief Justice Warren Burger, the Court reconfigured the standard to substantially narrow the range of justiciable claims by requiring that plaintiffs show that the injury is "distinct"-i.e., differentiated from the general populace-and "palpable" or "concrete," as opposed to speculative or hypothetical. ${ }^{27}$ The modern test requires that plaintiffs show (a) that they have suffered an "injury-in-fact" that was (b) caused by the defendant and that would (c) be redressable by a judgment in their favor as prerequisites to invoking the jurisdiction of an Article III court. ${ }^{28}$ Moreover, "a plaintiff must demonstrate standing separately for each form of relief sought" 29 and with the quantum of proof required at each stage of the litigation. ${ }^{30}$

Two factors further complicate the injury-in-fact test in cases brought against a governmental entity. First, if the plaintiff himself is the

24. See id. at $1921 \&$ n.36 (citing Ass'n of Data Processing Serv. Orgs., Inc. v. Camp, 397 U.S. 150,154 (1970)) (reviewing some examples of abstract interests that might, if harmed, establish injury, as provided by the Court in Data Processing).

25. 369 U.S. 186, 204 (1962). See generally Daniel Patrick Condon, Note, The Generalized Grievance Restriction: Prudential Restraint or Constitutional Mandate?, 70 GEO. L.J. 1157, 116465 (1982) (discussing the purpose of the personal stake requirement).

26. Nichol, supra note 20, at 1921.

27. See id. at 1923 ("[T]he injury standard demands harm that is "distinct and palpable." (quoting Warth v. Seldin, 422 U.S. 490, 501 (1975))).

28. Lujan v. Defenders of Wildlife, 504 U.S. 555, 560-61 (1992). The standing requirements for suing in state courts may vary significantly. See RogER BEERS, STANDING AND Rights of ACTION IN ENVIRONMENTAL LiTigation 5 (ALI-ABA Coursebook Paper, 2005), available at SK094 ALI-ABA (Westlaw) (discussing cases).

29. Friends of the Earth, Inc. v. Laidlaw Envtl. Servs. (TOC), Inc., 528 U.S. 167, 185 (2000).

30. Lujan, 504 U.S. at 561. Thus, "[a]t the pleading stage, general factual allegations of injury resulting from the defendant's conduct may suffice," but "[i]n response to a summary judgment motion, . . . the plaintiff can no longer rest on such 'mere allegations,' but must 'set forth' by affidavit or other evidence "specific facts." Id. (quoting FED. R. CIV. P. 56(e)). At the final stage, controverted facts "must be "supported adequately by the evidence adduced at trial." Id. (quoting Gladstone, Realtors v. Vill. of Bellwood, 441 U.S. 91, 115 n.31 (1979)). 
subject of the government action, it is usually clear that he has been injured and that a favorable judgment will redress the injury. ${ }^{31}$ If the asserted injury stems from the government's regulation or lack of regulation of someone else, by contrast, "much more is needed." 32 Second, a handful of federal statutes - primarily those governing federal environmental law-expressly confer standing on "any person," "citizen," or "party" to challenge agency actions. ${ }^{33}$ Although technically a plaintiff must independently satisfy the Lujan standard in cases brought pursuant to such statutes, citizen-suit provisions complicate the standing analysis by provoking the ban on generalized grievances. They represent a congressional determination to empower citizens to bring about a change in the way the Executive is enforcing the law. But in theory if injury-in-fact is truly a constitutional mandate, Congress has no power to endow the citizenry with standing to sue the FEC to prompt it to take enforcement action against a third party. Citizen-suit statutes thus highlight an inherent tension between the particularized injury requirement and standing to sue in many public law cases, a tension that is readily apparent in analyzing the various opinions in Lujan and Akins.

\section{Lujan and Statutory Standing}

Lujan involved a nonprofit organization's challenge to a rule promulgated by the Secretary of the Interior that interpreted the Endangered Species Act (ESA) ${ }^{34}$ so as to render the statute inapplicable to government actions taken abroad. ${ }^{35}$ The ESA instructs the Secretary to promulgate by regulation a list of threatened species and to define their critical habitats. ${ }^{36}$ It then requires that each federal agency, "in consultation with and with the assistance of the Secretary, insure that any action authorized, funded, or carried out by such agency . . . is not likely

31. Id. at $561-62$.

32. Id. at 562 .

33. E.g., Federal Election Campaign Act of 1971, 2 U.S.C. § 437g(a)(8)(A) (2000); Toxic Substances Control Act $\S 119,15$ U.S.C. § 2619(a) (2000); Endangered Species Act § 11, 16 U.S.C. $\S 1540(\mathrm{~g})$ (2000); Surface Mining Control and Reclamation Act $\S 520,30$ U.S.C. $§ 1270$ (a) (2000); Federal Water Pollution Control Act $\S 505$, 33 U.S.C. § 1365(a) (2000); Deepwater Port Act, 33 U.S.C. § 1515(a) (2000); Safe Water Drinking Act § 1449, 42 U.S.C. § 300j-8 (2000); Noise Control Act $\S 12$, 42 U.S.C. $\S 4911$ (a) (2000); Resource Conservation and Recovery Act $\S 702$, 42 U.S.C. $\S$ 6972(a) (2000); Clean Air Act § 304, 42 U.S.C. § 7604(a) (2000); Outer Continental Shelf Lands Act, 43 U.S.C. $§ 1349$ (a) (2000). The bulk of citizen-suit statutes appear in environmental legislation. See BEERS, supra note 28, at 2 (" $[\mathrm{M}]$ ost environmental statutes or amendments enacted after the Clean Air Act in 1970 contain such citizen suit provisions.").

34. 87 Stat. 884 (codified as amended at 16 U.S.C. $§ \S 1531-1544(2000)$ ).

35. Lujan, 504 U.S. at $557-58$.

36. 16 U.S.C. $\S \S 1533,1536$. 
to jeopardize the continued existence" of those species or their habitats. ${ }^{37}$ In 1978, the Fish and Wildlife Service and the National Marine Fisheries Service promulgated a regulation extending these obligations to actions taken in foreign nations, but proposed a revised regulation in 1983 that required only consultation for actions taken in the United States or on the high seas. ${ }^{38}$

The ESA contains a citizen-suit provision, which provides in pertinent part that "any person may commence a civil suit on his own behalf . . . to enjoin any person . . . who is alleged to be in violation of any provision of this chapter." ${ }^{39}$ A group of organizations devoted to environmental causes sued the Secretary, seeking a declaratory judgment that the new regulation was erroneous and an injunction requiring reinstatement of the old one. ${ }^{40}$ The Supreme Court held that the plaintiff groups lacked standing because they failed to show that any members were individually harmed with sufficient particularity or imminence. ${ }^{41}$ "By particularized," Justice Scalia wrote for the majority, "we mean that the injury must affect the plaintiff in a personal and individual way.",42

In an attempt to link the environmental threat to an actual personalized stake or interest in the judgment sought, the plaintiffs claimed that the agencies' lack of consultation regarding activities abroad increased the rate of extinction of endangered and threatened species, and that members of the plaintiff organizations had traveled to Egypt and Sri Lanka and observed endangered species in their traditional habitats, and intended to return. ${ }^{43}$ The plaintiffs' alleged injury was thus grounded in a procedural right created by virtue of the statute's requirement that agencies entrusted with the ESA's enforcement consult with each other regarding the impact of their actions on threatened species or habitats. ${ }^{44}$ The Court found it not cognizable irrespective of the statute's citizen-suit provision because the plaintiffs could not show how damage to the species injured them personally. ${ }^{45}$ They produced no

37. Id. $\S 1536(\mathrm{a})(2)$

38. Lujan, 504 U.S. at $558-59$ (citations omitted).

39. 16 U.S.C. $\$ 1540(\mathrm{~g})(2000)$.

40. Lujan, 504 U.S. at 559.

41. Id. at 564.

42. Id. at 560 n.1. As noted previously, this requirement dovetails with the prudential limitation on standing that precludes individual lawsuits to avenge "generalized grievances" shared by the populace as a whole.

43. Id. at 562-64 (quotations and citations omitted).

44. Id. at $562-63$.

45. Id. at 563 . 
concrete plans to visit the habitats in the future. ${ }^{46}$ Although the ESA required interagency consultation and empowered citizens to sue for its enforcement, the Lujan Court flatly rejected the notion "that the injuryin-fact requirement had been satisfied by congressional conferral upon all persons of an abstract, self-contained, noninstrumental 'right' to have the Executive observe the procedures required by law."47 The Court acknowledged that individuals can enforce procedural rights, but only if the procedures were "designed to protect some threatened concrete interest" of theirs that would independently give rise to standing. ${ }^{48}$ Thus, the inquiry circled back to particularized injury, regardless of the "right" to a particular procedure created by statute. ${ }^{49}$

Although the Supreme Court had previously recognized congressional power to create justiciable statutory rights even if no cognizable injury existed prelegislation, ${ }^{50}$ Lujan defeats the notion that Congress can legislate self-executing standing to the citizenry overall to vindicate such rights. Congress can only go so far, in other words, in exercising its settled authority to create justiciable statutory "rights" and in enhancing the justiciability of those rights with attendant citizen-suit provisions.

A plurality of the Court further concluded that the Lujan plaintiffs failed to satisfy the causation and redressability prongs. Justice Scalia deemed challenges to government programs, even if premised on violations of federal law, "rarely if ever appropriate for federal-court adjudication." 51 Because the funding agencies were not parties to the suit, whether a judgment against the Secretary would redress the alleged injury was "entirely conjectural."

Thus, while Lujan stands for the proposition that Congress cannot legislatively override the constitutional injury-in-fact requirement to

46. Id. at 564 .

47. Id. at 573

48. Id. at 573 n.8; see also Simon v. E. Ky. Welfare Rights Org., 426 U.S. 26, 41 n.22 (1976) ("When Congress has so acted, the requirements of Art. III remain: '(T)he plaintiff still must allege a distinct and palpable injury to himself, even if it is an injury shared by a large class of other possible litigants."” (quoting Warth v. Seldin, 422 U.S. 490, 501 (1975))).

49. Although there is arguably a distinction between abstract procedural rights and the right to information in that the latter produces a concrete, tangible commodity, the Akins Court found that the plaintiffs' injury lay in the "inability to obtain information," not in the void created by the absence of the information at issue. FEC v. Akins, 524 U.S. 11, 21 (1998).

50. See CHEMERINSKY, supra note 17, at 70 (discussing Trafficante v. Metro. Life Ins. Co., 409 U.S. 205 (1972)).

51. Lujan, 504 U.S. at 568 (plurality opinion) (quoting Allen v. Wright, 468 U.S. 737, 759-60 (1984)).

52. Id. at 568,571 . 
enable citizens to challenge government programs, the plurality indicated that causation and redressability are defeated whenever the actions of third parties could hypothetically interfere with the plaintiff's ability to achieve precise redress of the individualized relief alleged (if any) in administrative cases. The implications of Lujan practically translate into a ban on any suit against a government agency that does not involve clean challenges to regulatory activity by the regulated. In the latter circumstance, the case can easily be made that the government regulator directly caused the injury alleged by the regulated party. In more attenuated cases, such as those in which plaintiffs seek Executive enforcement of the campaign finance laws, the ultimate target is not even a party to the action; strict redressability, therefore, is utterly illusory.

\section{The Failures of Injury-in-Fact}

The Supreme Court's attempt to fashion a bright-line test that keeps federal judges from improperly usurping the Executive authority is laudable. The case-or-controversy language surely implies that something short of a political dispute must exist before the judiciary can be involved. ${ }^{53}$ Whether the injury-in-fact test effectively keeps courts from adjudicating noncases or noncontroversies within the meaning of Article III, however, is less evident. The Court has observed that the test "in no way depends on the merits of the plaintiff"s contention," 54 thus appearing to have assumed that it is sufficiently divorced from the merits to foster objectivity uninfluenced by a judge's political persuasions or the "sexiness" of the case. ${ }^{55}$ Yet the test's susceptibility to whim and subjectivity is perhaps the loudest complaint lodged against it.

Joined by Justice O'Connor, Justice Blackmun dissented in Lujan because the facts submitted raised at least a "genuine issue" as to whether the plaintiff organizations' members would return to the sites abroad as averred in their affidavits, which is all that the summary judgment standard of Fed. R. Civ. P. 56 requires; the dissent thus questioned the plurality's requirement of "concrete plans" as "empty formality." 56 Nothing prevented the affiants from "simply purchasing

53. Cf. Nichol, supra note 20, at 1923 ("The Court's goals . . are both ascertainable and ... laudable.").

54. Warth v. Seldin, 422 U.S. 490, 500 (1975).

55. See Nichol, supra note 20, at 1923-24 (discussing the "line of demarcation between the presentation of 'cases' and the mere airing of political disagreements").

56. Lujan, 504 U.S. at 592 (Blackmun, J., dissenting). 
plane tickets." 57 Justice Blackmun "fear[ed] the Court's demand for detailed descriptions of future conduct will do little to weed out those who are genuinely harmed from those who are not," and require "more and more particularized showings of future harm."

The concerns Justice Blackmun outlined were not idle. Requiring the judiciary to employ a standing inquiry that depends on an ultimately subjective analysis of how much harm is enough harm yields more - not less-power for unelected judges. As the varying opinions in Lujan itself demonstrate, the injury-in-fact test enables judges to resolve debates over whether affidavits are sufficiently detailed in wildly disparate ways that may be equally legitimate under its three prongs. As a result, case law under Lujan is fraught with inconsistencies. ${ }^{59}$ The injury-in-fact test tolerates the outcome-determinative standing adjudication that it was designed to avoid, all the while bearing no transparent correlation to the strength of the claim on the merits. A judge could require a more particularized showing of harm if she prefers to dismiss the case, and accept a vague showing if she wishes to reach the merits. Hypothetically, too, injury-in-fact can easily be overcome by recruiting "injured" plaintiffs to join a political organization's complaint simply for purposes of surviving what would otherwise be a difficult standing challenge to an overly broad attack on a government program. ${ }^{60}$ The Supreme Court has rejected a quantitative test for injury, ${ }^{61}$ so the test is both underinclusive (excluding legitimate claims based on pleading technicalities) and potentially overinclusive.

57. Id.

58. Id. at 593.

59. See generally Gene R. Nichol, Jr., Standing for Privilege: The Failure of Injury Analysis, 82 B.U. L. REV. 301 (2002) (discussing how standing law is inconsistent). Many have taken the view that "as a body of law, the standing doctrine has failed," $i d$. at 304 , both because the standard is inherently flawed and inflexible by design, and because the Supreme Court has interpreted its creation too restrictively. See, e.g., Lisa Schultz Bressman, Judicial Review of Agency Inaction: An Arbitrariness Approach, 79 N.Y.U. L. REV. 1657, 1671 (2004) (explaining the disappointment due to the Supreme Court's restrictive interpretation of the injury-in-fact requirement).

60. See Chemerinsky, supra note 17, at 62 (describing how, after the Supreme Court determined in Sierra Club v. Morton, 405 U.S. 727 (1972), that the Sierra Club lacked standing to sue to prevent the construction of a ski resort because there was no allegation that its members had used the area where the resort was to be constructed, Justice White is quoted as saying, "'Why didn't the Sierra Club have one goddamn member walk through the park and then there would have been standing to sue?"; the plaintiffs amended their complaint accordingly on remand (quoting BOB WOODWARD \& SCOTT ARMSTRONG, THE BRETHREN 164 n.*(1979))).

61. Steven G. Davison, Standing to Sue in Citizen Suits Against Air and Water Polluters Under Friends of the Earth, Inc. v. Laidlaw Environmental Services (TOC), Inc., 17 TUL. ENVTL. L.J. 63, 66 \& n.21 (2003) (citing United States v. Students Challenging Regulatory Agency Procedures, 412 U.S. 669, 689 n.14 (1973)). 
Proposed alternatives to the injury-in-fact standard range from a straightforward merits test ${ }^{62}$ to a redefinition of injury to recognize subcategories of cognizable interests ${ }^{63}$ to, perhaps most prominently, a purely statutory inquiry hinging on congressional intent. ${ }^{64}$ Others have challenged these critiques by attempting to unearth the historical underpinnings of the Constitution's case-or-controversy requirement, arguing that the Framers envisioned the federal courts as places for hearing actual and distinctly personal grievances, and that Lujan properly (if not clumsily) aims to cabin their role in our structure of government. ${ }^{65}$

Whether Congress can legislate standing to sue has been at the heart of this dialogue. ${ }^{66}$ Nowhere is this question more salient than where review of government action is concerned. We live in an era of extraordinary tension regarding the powers of Congress vis-à-vis the autonomy of the Executive Branch. Whether private citizens can invoke the jurisdiction of the third branch of government, at Congress's behest, to review Executive action is a question with everyday implications. It is particularly salient in the area of campaign finance and election reform, which many view as striking at the heart of democracy itself. Because it provides that Congress can endow citizens with standing to sue the FEC to prompt it to enforce the law, the Supreme Court's decision in FEC v. Akins $^{67}$ is of greater import than has been recognized.

62. See William A. Fletcher, The Structure of Standing, 98 YALE L.J. 221, 234 (1988) (stating that "standing is a jurisdictional question, involving a preliminary look at the merits").

63. See Gene R. Nichol, Jr., Rethinking Standing, 72 CAL. L. REv. 68, 89 (1984) (stating three ways an interest cognizable by law can be created); see also Nichol, supra note 20, at 1942-43 (arguing that injury should take into account the cognizability of the underlying interest in addition to the actuality of the harm).

64. See Sunstein, supra note 10, at 616-17 (noting "the question of standing is for congressional rather than judicial resolution").

65. See generally James Leonard \& Joanne C. Brant, The Half-Open Door: Article III, the Injury-in-Fact Rule, and the Framers' Plan for Federal Courts of Limited Jurisdiction, 54 RUTGERS L. REV. 1 (2001) (reviewing the evolution of the injury-in-fact requirement and arguing that it reflects the Framers' views); Ann Woolhandler \& Caleb Nelson, Does History Defeat Standing Doctrine?, 102 MICH. L. REV. 689 (2004) (arguing that historically cases saw a "constitutional dimension to standing doctrine").

66. Justice Scalia framed the same question as "whether the public interest . . . in agencies' observance of a particular, statutorily prescribed procedure can be converted into an individual right by a statute that denominates it as such, and that permits all citizens . . . to sue." Lujan v. Defenders of Wildlife, 504 U.S. 555, 576-77 (1992) (punctuation omitted).

67. 524 U.S. 11 (1998). 


\section{B. Informational Injury and $\mathrm{FEC}$ v. Akins}

Akins addressed the question of whether individual voters' challenges to the FEC's refusal to take enforcement action against someone else presented a case or controversy within the meaning of Article III. In finding standing, the Court drew three conclusions in derogation of Lujan. First, it indicated that Congress can create a statutory "right" that the populace can enforce in court by sheer operation of the statute. Second, it lifted the ban on Article III courts' adjudication of grievances that are widely shared so long as the harm itself is not "abstract." And, third, it diluted the causation and redressability requirements beyond reasonable recognition. Yet the full implications of Akins have only marginally been explored. ${ }^{68}$

Akins arose from the Commission's determination that the American Israel Public Affairs Committee (AIPAC) is not a "political committee" as defined by the FECA and its refusal to require AIPAC to make disclosures required under the Act. ${ }^{69}$ A group of voters that opposed AIPAC's views filed a complaint with the FEC alleging that AIPAC was a political committee that failed to comply with the FECA's disclosure requirements. It asked the FEC to force AIPAC to release information required of political committees. ${ }^{70}$

68. See also Nichol, supra note 59, at 336 ("[I]n Federal Election Commission v. Akins, the Court backed away from Lujan's premises. In Akins, the Court easily recognized a statutory grant of standing even though some Justices would have regarded the informational claim asserted as a generalized grievance."); cf. Trevor W. Morrison, Private Attorneys General and the First Amendment, 103 MicH. L. REV. 589, 624 n.158 (2005) ("Applied broadly, this approach might seem to signal a repudiation of Lujan's conception of "injury in fact.").

69. As the Supreme Court explained in Akins, "the FECA seeks to remedy any actual or perceived corruption of the political process in several important ways." 524 U.S. at 14. The FECA prohibits corporations from making contributions or expenditures in connection with elections to any political office, including primary elections. 2 U.S.C. $\S 441 \mathrm{~b}$ (a) (2000). It imposes limits on the amounts individuals and entities qualifying as "political committees" under the Act can contribute or spend in coordination with a candidate for federal political office. Id. $\S \S 441 \mathrm{a}(\mathrm{a})-(\mathrm{b}), 441 \mathrm{~b}$. A "political committee" includes "any committee, club, association or other group of persons" which receives more than $\$ 1000$ in "contributions" or makes more than $\$ 1000$ in "expenditures" in any given year, 2 U.S.C. $\$ 431(4)(A)(2000)$, "for the purpose of influencing any election for Federal office," id. $\S 431(8)(\mathrm{A})(\mathrm{i}),(9)(\mathrm{A})(\mathrm{i})$. Political committees must register with the Commission, appoint a treasurer, maintain information regarding contributors, track disbursements, and file periodic reports setting forth this and other information in great detail. Id. $\S \S 432-434$.

70. Akins, 524 U.S. at 15-16. The FEC concluded that AIPAC's communications did count as "expenditures" for purposes of the FECA's definition of "political committee," but nonetheless exempted AIPAC from its requirements and dismissed the voters' complaint. Id. at 17-18, 29. The district court and the D.C. Circuit ultimately reached the merits, finding that the FEC misinterpreted the statute's definition of "political committee." See Akins v. FEC, 101 F.3d 731, 744 (D.C. Cir. 1996) (en banc) (finding that the FEC's decision to dismiss appellant's complaint was "based on its 
In finding that the plaintiffs had standing to sue the FEC for refusing to take enforcement action against AIPAC, Justice Breyer, writing for the majority, unambiguously recognized Congress's power to define constitutional standing: ${ }^{71}$ "[T]he informational injury at issue here, directly related to voting, the most basic of political rights, is sufficiently concrete and specific" so as not to "deprive Congress of constitutional power to authorize its vindication in the federal courts." 72 Because the FECA required the disclosure of information, the deprivation of such information established standing. ${ }^{73}$ This holding presupposes that Congress is empowered to legislate an "injury" previously unknown to the law. The Court rejected the FEC's argument "that Congress lacks the constitutional power to authorize federal courts to adjudicate this lawsuit." 74

The Akins approach to congressional power to define justiciability stands in stark contrast with that reflected in Lujan, which hinged standing analysis on the individual's private injury as distinct from the statutory terms that gave rise to the injury. ${ }^{75}$ In Lujan, Justice Scalia made clear that "[i]t makes no difference" what Congress attempts to do by way of legislation when it comes to Article III standing-the Constitution always requires injury-in-fact. ${ }^{76}$ The Akins majority, by contrast, based its standing inquiry on the purpose of the FECA's enforcement provision, and refused to accept the proposition-implicit in

mistaken interpretation of $\S 431(4)(A) ”)$, rev'd on other grounds, 524 U.S. 11 (1998).

71. Justice Breyer observed that the prudential standing element is satisfied because Congress empowered " "[a]ny party aggrieved" " by the FEC's dismissal of an administrative complaint or its failure to timely act on such a complaint to sue in district court. Akins, 524 U.S. at 19 (quoting § $437 \mathrm{~g}(\mathrm{a})(8)(\mathrm{A})(2000))$ (alteration in original). Justice Breyer construed this language as evincing "a congressional intent to cast the standing net broadly." Id. at 19-20 (citing the Administrative Procedure Act which states that "those 'suffering legal wrong' or 'adversely affected or aggrieved . . . within the meaning of a relevant statute' may seek judicial review of agency action”); Buckley v. Valeo, 424 U.S. 1, 66-67 (1976). Courts have interpreted the Akins Court's characterization of the "aggrieved party" language as holding that Congress waives all prudential limitations on standing except for the "zone of interest" test when it grants "aggrieved" parties the right to sue. See, e.g., Bangura v. Hansen, 434 F.3d 487, 499 (6th Cir. 2006) (discussing the application of the "zone of interest test" as it applies to parties with standing to sue).

72. Akins, 524 U.S. at $24-25$.

73. Id. at 25 .

74. Id. at 20 .

75. See Nichol, supra note 59, at 334 (arguing that the Court's "effort to make the injury requirement a principal determinant" of the federal courts' limited role in our government has "not succeeded," and that the opinions are "inconsistent and contradictory").

76. See Lujan v. Defenders of Wildlife, 504 U.S. 555, 566 (1992) (“[I]t makes no difference that the general-purpose section of the ESA states that the Act was intended in part 'to provide a means whereby the ecosystems upon which endangered species and threatened species depend may be conserved."') (quoting 16 U.S.C. § 1531(b) (1990)). 
the FEC's arguments and Justice Scalia's dissent - that the statute itself is ultra vires.

Whereas the Lujan plurality rejected the plaintiffs' argument that they suffered a generalized but justiciable "procedural injury" under the ESA's citizen-suit provisions, ${ }^{77}$ the Akins Court again diverted from Lujan by defeating the FEC's contention that the voters raised only a "'generalized grievance." "78 The fact that informational injury inflicted on voters "is widely shared [does] not deprive Congress of constitutional power to authorize its vindication in the federal courts." ${ }^{, 79}$ The Court distinguished harms of "an abstract and indefinite nature," such as "injury to the interest in seeing that the law is obeyed."

The Akins Court thus sketched out some sort of compromise between a purely ideological injury that is not cognizable and one that, though widely shared, is something more concrete than pure ideology, albeit not particularized. At both poles, the grievance is "generalized" in the sense that many people share it, so the constitutional objection under Akins lies in the nature of the injury. ${ }^{81}$ Pure distaste in government activity presumably still has a uniquely political solution post-Akins. Short of that, Congress can define "injuries" that are cognizable notwithstanding that the public as a whole suffers them. The Article III injury requirement is satisfied so long as the plaintiff identifies injurypotentially any injury - to an express statutory "right." 82 And in the FECA, Congress created just such a nonabstract injury in establishing a right to third-party information. The breadth of the citizen-suit provision expressly allowing for standing to vindicate such statutory injury, moreover, waives any prudential objections that might remain regarding citizen standing. ${ }^{83}$

Notably, Akins did not superimpose Lujan on FECA standing by erecting what could have been a two-tiered injury standard, whereby a complainant must prove both that it was denied access to information and that such denial injured a live and specific interest in some additional way (by, for example, making it difficult for a voter to

77. Id. at $573-74$.

78. Akins, 524 U.S. at 23 .

79. Id. at 25 .

80. Id. at $23-24$

81. See 1 Laurence H. Tribe, American Constitutional Law 424 (3d ed. 2000) ("But a court ... should not close its eyes to the nature of the substantive right asserted and should not forget to inquire whether the nature of the particular injury, however widely inflicted, is such as to impede the effective operation of majoritarian processes.").

82. CHEMERINSKY, supra note 17 , at 72.

83. See supra notes 14,71 and accompanying text. 
evaluate a particular candidate implicated by the information in a particular election). ${ }^{84}$ This is perhaps where the greatest misunderstanding of the Akins holding lies. Courts and the FEC's lawyers have added a layer of analysis on Akins that would require a showing that a widely shared lack of FECA information also causes a distinct, albeit related, harm to the plaintiff. ${ }^{85}$ This is an understandable attempt to harmonize Lujan's particularized injury requirement with Akins, particularly as Lujan conflated the prudential ban on generalized grievances (which Congress inherently waived with a citizen-suit provision) with the Article III minima. But it is inconsistent with the holding of Akins itself. Although the Court noted that there was "no reason to doubt" that the information sought by AIPAC would be useful to it, ${ }^{86}$ this comment was dicta and not integral to its finding of constitutional standing.

The third and most prominent way in which Akins conflicted with Lujan was its treatment of causation and redressability. AIPAC easily cleared the hurdle that Justice Scalia described as "[t]he most obvious problem" with Lujan. ${ }^{87}$ Lujan established that a greater showing of injury is needed when a plaintiff sues to prompt government regulation of someone else. ${ }^{88}$ Under such circumstances, causation and redressability " "depend[] on the unfettered choices made by independent actors not before the courts." 89 Under Lujan, such plaintiffs must "adduce facts showing that those choices have been or will be made in such manner as to produce causation and permit redressability of injury." In other words, plaintiffs must be prepared to establish "facts" as to the occurrence of future events.

Akins presented the third-party scenario outlined in Lujan, with opposite results. The Court was satisfied that the injury was redressable even though the FEC was not in actual possession of the information sought by AIPAC and thereby tolerated the inevitably speculative causation and redressability showing that would otherwise constrain plaintiffs seeking to spur regulation of a third party. Although the FEC remained at leisure to "decide[] in the exercise of its discretion not to require AIPAC to produce the information," this unknown did not defeat

84. Cf. Akins, 524 U.S. at 21 (musing that "[t]here is no reason to doubt [the respondents'] claim that the information would help them . . . in a specific election").

85. See infra notes 99-123 and accompanying text.

86. Akins, 524 U.S. at 21

87. Lujan v. Defenders of Wildlife, 504 U.S. 555, 568, 571 (1992) (plurality opinion).

88. Id. at 562 (majority opinion).

89. Id. (quoting ASARCO Inc. v. Kadish, 490 U.S. 605, 615 (1989) (plurality opinion)).

90. Id. (emphasis added). 
Article III causation. ${ }^{91}$ The Court found that causation and redressability were satisfied by the mere fact that a reviewing court was empowered to "set aside the agency's action and remand the case."" Taken to its logical extreme, this finding would render causation and redressability per se satisfied in all administrative cases. The fact that AIPAC was not a party to the case but could conceivably take actions to frustrate redressability did not even factor into the Court's analysis.

At bottom, what the Akins Court refused to do under the auspices of Article III standing was render the FECA enforcement provision a nullity. Although well-established precedent generally precludes judicial review of Executive decisions not to enforce a statute, ${ }^{93}$ the Akins Court distinguished the FECA as a statute that "explicitly indicates the contrary." assailed "[t]he provision of law at issue in this case [a]s an extraordinary one," because it empowers private parties to compel an agency to regulate a third party. ${ }^{95}$ By making clear that it was not willing to entertain a challenge to the "provision of law" itself, the Akins majority grounded its standing decision in the language of that law instead of the facts peculiar to the individual plaintiffs before it. In doing so, it elevated Justice Kennedy's concurrence in Lujan, in which he reiterated that Congress is empowered to define injuries that give rise to a cause of action that did not exist at common law. ${ }^{96}$

Thus, whereas Akins focused on the terms of the statute on the theory that Congress can legislate standing by creating a "right" to information

91. Akins, 524 U.S. at 25 (citing Citizens to Preserve Overton Park, Inc. v. Volpe, 401 U.S. 402, 410 (1971); Abbott Labs. v. Gardner, 387 U.S. 136, 140 (1967)).

92. Id.

93. See Heckler v. Chaney, 470 U.S. 821, 831 (1985) ("This Court has recognized on several occasions over many years that an agency's decision not to prosecute or enforce, whether through civil or criminal process, is a decision generally committed to an agency's absolute discretion.").

94. Akins, 524 U.S. at 26.

95. Id. at 29-30 (Scalia, J., dissenting) (emphasis added).

96. Lujan v. Defenders of Wildlife, 504 U.S. 555, 580 (1992) (Kennedy, J., concurring); see also Morrison, supra note 68, at 624 n.158 ("Arguably, . . . Akins may signal a shift in the direction of Justice Kennedy's concurring opinion in Lujan, which did not go so far as to say that assessing individualized 'injury in fact' is an entirely pre-legal exercise, but instead simply stressed that Congress must speak clearly and carefully when creating enforceable legal rights .....”).

Lujan was one of several cases in the mid-to-late $1980 \mathrm{~s}$ that halted a "move toward liberalization of standing," that had begun in the 1960s and had had a "net effect of . . . transform[ing] the APA standing provisions from a screen against bystander suits into an open sieve." Thomas W. Merrill, Capture Theory and the Courts: 1967-1983, 72 CHI.-KENT L. REV. $1039,1077,1076$ (1997). That is, prior to the Lujan line of cases, a plaintiff did not "have to show injury to a common law right or the existence of a special legislatively created cause of action. It was enough to show some connection to the government decision being challenged and to make arguments bearing some relationship to a federal regulatory scheme." Id. 
that is enforceable by the public at large, Lujan denied standing notwithstanding the language and purpose of the ESA because the facts relating to the individual plaintiff failed to demonstrate imminent, particularized harm that would be redressed by the declaratory judgment and injunction sought. ${ }^{97}$ Because Lujan remains a leading case on standing, courts have strained to harmonize the two cases, an effort which has led to confusing standing jurisprudence and more litigation. ${ }^{98}$ Courts should instead acknowledge that Akins substantially departed from Lujan, and focus on determining which line of authority to apply in non-FECA cases.

\section{Relitigation of Akins}

What Justice Blackmun expressed as rhetorical disbelief in his Lujan dissent - that Lujan standing analysis would enable the Executive Branch to simply ignore the Supreme Court's construction of a governing statute $^{99}$ - has emerged in FECA standing litigation under Akins. By rigidly relying on the Lujan analysis, the FEC has succeeded in muddling the clear holding of Akins so as to force courts to "decide" the issues the Supreme Court already resolved in Akins. ${ }^{100}$ Not only does the Commission's defensive strategy misdirect resources, it necessitates complex standing litigation that is expensive for private parties to undertake. As a result, relitigation of Akins operates as a barrier to

97. Before either Lujan or Akins, the Supreme Court, in United States v. Richardson, 418 U.S. 166 (1974), dismissed on standing grounds a taxpayer suit challenging the Government's failure to disclose the expenditures of the Central Intelligence Agency. Id. at 170. Just as Justice Scalia relied on Richardson in his Lujan opinion, Lujan, 504 U.S. at 575, he discussed it at length in his Akins dissent, 524 U.S. at 31-36 (Scalia, J., dissenting). The Richardson plaintiffs alleged that the agency violated the constitutional requirement that "'a regular Statement and Account of the Receipts and Expenditures of all public Money shall be published from time to time." 418 U.S. at 167-68 (citing U.S. CONST. art. I, § 9, cl. 7). Justice Scalia explained in Akins that the Richardson plaintiffs' “'aggrievement' was precisely the 'aggrievement' [asserted in Akins]: the Government's unlawful refusal to place information within the public domain." Akins, 524 U.S. at 32 (Scalia, J., dissenting). Indeed, the Richardson injury was even less tenuous, as the government was in actual possession of the information sought. The Court found such a claim a nonjusticiable "generalized grievance" because "the impact on [the plaintiff] is plainly undifferentiated and "common to all members of the public." Richardson, 418 U.S. at 176-77. Because the showing of actual individual harm flowing from the deprivation of the information found lacking was simply not required by the Akins Court, Richardson would have come out differently under Akins.

98. See infra Part II.C.

99. Lujan, 504 U.S. at 605 (Blackmun, J., dissenting).

100. See Morrison, supra note 68, at 624 n.158 (citing McConnell v. FEC, 540 U.S. 93, 228-29 (2003); Friends of the Earth, Inc. v. Laidlaw Envtl. Servs. (TOC), Inc., 528 U.S. 167, 180-81 (2000)) ("Akins did not overrule Lujan, and subsequent decisions have continued to cite Lujan as binding authority."). 
reaching merits review of certain FEC decision making that the citizensuit provision expressly opens to scrutiny.

The trouble the Akins Court created by failing to repudiate Lujan is exemplified in a pair of cases, Buchanan v. FEC ${ }^{101}$ and Natural Law Party of the United States $v$. FEC. ${ }^{102}$ Both were actions brought by thirdparty presidential candidates challenging the FEC's dismissal of administrative complaints alleging improprieties by the Committee on Presidential Debates (CPD) in connection with the 1996 election. ${ }^{103}$ The FEC argued that because the elections were over by the time it dismissed the administrative complaints, no live injuries existed and the courts were powerless to redress past harm. ${ }^{104}$ The Commission essentially took the position that injury-in-fact is categorically impossible to satisfy in FECA cases because, as a practical matter, elections are short-lived. The nine-month election cycle makes it difficult to prove " 'imminent' injury" at the time the complaint is filed in federal court, the argument went, leaving voters and defeated candidates susceptible to critique that the injuries alleged are either "some day" intentions" or "“[p]ast exposure to illegal conduct" "that do not suffice to establish injury-in-fact under Lujan. ${ }^{105}$

Both courts denied the FEC's motions to dismiss for lack of standing, and ultimately identified the problem-implicit in the majority decision in Akins, and in Justice Scalia's dissent - that the Akins majority attempted to avoid: that "the acceptance of the FEC's overly narrow construction of 'injury in fact' would be tantamount to shielding from judicial review many, if not all, election cases," 106 thus "read[ing] FECA's judicial review provision out of the statute without any constitutionally sound rationale." 107 But in both cases, it took carefully

101. 112 F. Supp. 2 d 58 (D.D.C. 2000).

102. 111 F. Supp. 2d 33 (D.D.C. 2000); see also Becker v. FEC, 230 F.3d 381, 383 (1st Cir. 2000) (involving challenge of FEC debate regulations allowing corporate funding of certain debatestaging organizations).

103. As the Buchanan court explained, " $[t]$ he $C P D$ is a private, non-profit corporation formed by the two major parties in 1987 for the purpose of sponsoring presidential debates." $112 \mathrm{~F}$. Supp. $2 \mathrm{~d}$ at 61. It staged presidential debates leading up to the 1996 election and others before it. Id.

104. Natural Law Party, 111 F. Supp. 2d at 42.

105. Lujan v. Defenders of Wildlife, 504 U.S. 555, 564 (1992).

106. Natural Law Party, 111 F. Supp. $2 \mathrm{~d}$ at 42 . The FEC did not argue that the plaintiffs lacked prudential standing in any of these cases, which appears to be the only point it took well from the Akins decision. See, e.g., Buchanan, 112 F. Supp. $2 \mathrm{~d}$ at 65 n.6 ("The FEC does not challenge plaintiffs' prudential standing to bring this case because it is clear that candidates, political parties, and voters are within the 'zone of interests' protected by FECA."); Natural Law Party, 111 F. Supp. $2 \mathrm{~d}$ at 43 ("Defendant does not argue that plaintiffs lack prudential standing, and, indeed, plaintiffs' claims would seem to fall squarely within the 'zone of interests' to be protected by the FECA.").

107. Buchanan, 112 F. Supp. 2d at 69. 
rendered decisions following costly litigation for the district courts simply to reach the conclusion that Akins says what it says.

If the FEC's circular standing analysis was correct, the Akins plaintiffs would certainly have had no standing. In Akins itself, AIPAC was alleged to have helped defeat one of the Akins plaintiffs, Paul Findley, in the 1982 congressional election. ${ }^{108}$ The administrative complaint, filed in 1989, claimed that AIPAC had made illegal campaign contributions $^{109}$ with respect to elections (one must presume) that occurred in the past. ${ }^{110}$ Neither the historical nature of the alleged election-related injury nor the time-lag between election and enforcement activity factored into the Supreme Court's standing inquiry. Still, the Buchanan and Natural Law Party courts felt compelled to undertake a detailed rebuttal of several pre-Akins cases relied upon by the $\mathrm{FEC}^{111}$ to argue not only that the alleged injury was insufficiently " concrete and particularized," but that it was " conjectural or hypothetical" "within the meaning of the tripartite Lujan test. ${ }^{112}$ The FEC's argument created a double-bind: a FECA plaintiff's harm is either too stale or too speculative, rendering FEC nonenforcement decisions largely unreviewable despite the citizen-suit provision of the FECA itself.

The FEC took on Akins again in Kean for Congress Committee $v$. $F E C^{113}$ after it was challenged for dismissing a defeated congressional candidate committee's administrative complaint alleging that the Council for Responsible Government (CRG) violated numerous FECA prohibitions in connection with its advertisements against the candidate, Tom Kean, Jr., in advance of the 2000 election. ${ }^{114}$ The FEC moved to dismiss, arguing that standing was lacking because the Kean Committee failed to prove that Kean would run for office again, ${ }^{115}$ and accused the plaintiff of taking "a "radical position" in basing its standing on the FECA. $^{116}$ The Commission argued that the lack of FECA-related information, without more, was an insufficient injury under Lujan-even though it was squarely satisfied in Akins-because the plaintiff did not

\footnotetext{
108. Akins v. FEC, 101 F.3d 731, 734 (D.C. Cir. 1996) (en banc), rev'd on other grounds, 524 U.S. 11 (1998) 
produce evidence to show particularized political injury to an active candidate for office. The district court found that the FEC's argument "misconstrues the holding of Akins," which found injury-in-fact because the plaintiff sought information under the FECA. ${ }^{117}$ As in Akins, then, to deny standing in Kean would have been to nullify the enforcement provisions of the Act.

Courts continue to adjudicate the core holding of Akins in FECA informational suits, and the confusion Akins created by glossing over the injury-in-fact standard has made mischief in other contexts. Courts struggle with the question whether some additional injury beyond mere deprivation of information is necessary to satisfy Article III standing in non-FECA cases involving a statutory right to information. A few have distinguished the holding of Akins as "narrowly focused upon the widely held fundamental right of voting and the lack of information was claimed to be injurious to that right." 118 On the other end of the spectrum, a court ventured to state that a "necessary injury in fact might . . . be premised upon the . . violation of the Act itself." 119 It expansively read Akins as recognizing "injury sufficient to confer standing resulting from violation of "statute which ... . does seek to protect individuals such as respondents from the kind of harm they say they have suffered." "120

A majority of cases applying Akins appears to fall between these poles by requiring what Akins did not-some showing of injury in addition to a deprivation of information. ${ }^{121}$ Even in the case of the voter-

117. Id. (citing Warth v. Seldin, 422 U.S. 490, 514 (1975)).

118. Heartwood, Inc. v. U.S. Forest Serv., No. 1:00-CV-683, 2001 WL 1699203, at *10 (W.D. Mich. Dec. 3, 2001). In Atlantic States Legal Foundation v. Babbitt, a district court rejected a nonprofit environmental organization's standing to challenge the EPA's failure to produce an environmental impact statement (EIS) before issuing a permit allowing destruction of cormorant birds. 140 F. Supp. 2d 185, 194 (N.D.N.Y. 2001). The court distinguished Akins as having arisen in the "special context of voters' rights" and as uniquely "affected by the fact that the alleged informational injury was directly related to the core constitutional right to vote." Id. at $193 \mathrm{n} .8$. It concluded that "the notion of informational harm, without more, does not confer standing in a NEPA case as it is inconsistent with the requirement of establishing concrete and particularized harm" under Lujan. Id. at 194. However, the plaintiff did not rely upon the sheer absence of information to justify its standing. It articulated numerous theories of injury to aesthetic enjoyment and alleged that the lack of an EIS prevented it from distributing information about cormorant management, assessing the impact of the defendants' activities, publishing information to its members, and participating in the public commentary process guaranteed by the NEPA. Id. at 192-94. None were considered sufficient to establish a justiciable case under Lujan.

119. See Bloom v. NLRB, 153 F.3d 844, 849 n.2 (8th Cir. 1998) (noting that plaintiff's injury was premised on an employee petition for review of an order of the National Labor Relations Board approving settlement agreements between the employer and the union and dismissing his unfair labor practice charges), vacated, 525 U.S. 1133 (1999).

120. Id. (quoting FEC v. Akins, 524 U.S. 11, 22 (1998)).

121. See, e.g., Ethyl Corp. v. EPA, 306 F.3d 1144, 1147-48 (D.C. Cir. 2002) (finding that automobile manufacturer had standing to sue for judicial review of the EPA's framework of closed 
plaintiff seeking FECA information, where the Supreme Court has itself acknowledged that the potential use for election-related information is self-evident, ${ }^{122}$ courts have required that plaintiffs separately demonstrate how they would use the information in voting. ${ }^{123}$

Only months ago, the D.C. Circuit in Citizens for Responsibility and Ethics in Washington [CREW] v. FEC $C^{124}$ relied upon a pre-Akins decision called Common Cause v. FEC ${ }^{125}$ to deny standing in a case challenging the FEC's dismissal of an administrative complaint under the FECA's citizen-suit provision and, in doing so, markedly marginalized Akins. Plaintiff CREW, a public interest group, challenged the receipt by President Bush's 2004 presidential campaign of a contact list containing information regarding conservative activists. ${ }^{126}$ The FEC conducted an investigation and agreed that the list constituted an in-kind contribution under the FECA, and that the campaign violated the law, but declined to take further action. ${ }^{127}$ CREW sued on an informational standing theory, claiming that an order requiring the FEC to assign a dollar value to the

proceedings for new motor vehicle testing based on the "[plaintiff's] fairly detailed description of how the information that open rulemaking proceedings provide would prove useful to it"); Hodges v. Abraham, 300 F.3d 432, 444 (4th Cir. 2002) (holding that NEPA plaintiffs possess a procedural right to have the Executive observe procedures mandated by law " without meeting all the normal standards for redressability and immediacy" but only if " the procedures in question are designed to protect some threatened concrete interest of his that is the ultimate basis of his standing" (quoting Lujan v. Defenders of Wildlife, 504 U.S. 555, 572 n.7, 573 n.8 (1992))); Kean for Cong. Comm. v. FEC, 398 F. Supp. 2d 26, 34-35 (D.D.C. 2005) (considering both the statutory grant of right to requested information and whether "there is no reason to doubt" the usefulness of the information to plaintiff (quoting Akins, 524 U.S. at 21)); Alliance for Democracy v. FEC, 335 F. Supp. 2d 39, 48 (D.D.C. 2004) (construing Akins in FECA case as requiring that "plaintiffs . . show how [the information they seek] could have a concrete effect on plaintiffs' voting in future elections involving different candidates"); Ga. River Network v. U.S. Army Corps of Eng'rs, 334 F. Supp. 2d 1329, 1346 (N.D. Ga. 2003) (finding no standing under Akins where plaintiff suffered no injury as a result of delay in receiving notice of a permit).

122. See Akins, 524 U.S. at 20, 24-26 (observing that information sought would "help voters understand who provides which candidates financial support" and that voting is a core constitutional right).

123. In one FECA case, the court construed Akins as requiring that "plaintiffs ... show how [the information they seek] could have a concrete effect on plaintiffs' voting in future elections involving different candidates." Alliance for Democracy, 335 F. Supp. $2 \mathrm{~d}$ at 48.

124. 475 F.3d 337 (D.C. Cir. 2007).

125. Although Common Cause v. FEC, 108 F.3d 413 (D.C. Cir. 1997) (per curiam), predated the Supreme Court's decision in Akins, the D.C. Circuit itself had already decided Akins v. FEC, 101 F.3d 731 (D.C. Cir. 1997) (en banc), vacated and remanded on other grounds, 524 U.S. 11. In its Akins decision, the D.C. Circuit held that " "[a] voter deprived of useful information at the time he or she votes suffers a particularized injury' sufficient to create standing," but unlike the Supreme Court, the D.C. Circuit "expressly limited [its] recognition of this injury to those cases where the information denied is ... useful in voting." Common Cause, 108 F.3d at 418 (quoting Akins, 101 F.3d at 737).

126. CREW, at $337-38$.

127. Id. at 338 . 
list would inure to the educational benefit of the voting public. ${ }^{128}$ The district court dismissed the complaint for lack of standing, finding under Akins that there was "reason[] to doubt" that the list's value constituted information that would be useful to CREW in voting, because it had no members and-unlike the Akins and Kean plaintiffs-was not a "participant[] in the political election and campaign process." 129 The D.C. Circuit affirmed, distinguishing the Akins plaintiffs on the grounds that they had "wanted certain information so that they could make an informed choice among candidates in future elections," whereas "CREW cannot vote." 130

Unnecessarily, the D.C. Circuit's narrow treatment of Akins's reach did not stop with singling out voter-plaintiffs. First, the court went out of its way to express its "wonder why the case is not moot," as "[t]he election is over; President Bush is constitutionally barred from running again; and Vice President Cheney has announced that he will not run." ${ }^{\text {"131 }}$ This language falls short of an outright suggestion that the only voterplaintiffs who could conceivably have standing to sue under the FECA's citizen-suit provision are those able to show injury to their ability to cast an informed vote in an imminent election, which would significantly limit the already circumscribed scope of $\S 437 \mathrm{~g}(\mathrm{a})(8)$.

Second, the D.C. Circuit's causation and redressability analysis challenged that of the Akins majority. Not unlike Justice Scalia in his Akins dissent, the D.C. Circuit indicated that the fact that "the Commission has no authority to order anyone to report anything" is preclusive of standing. ${ }^{132}$ Even if the FEC brought an enforcement action, the court observed further, there is no required redress. ${ }^{133}$ In other words, because CREW - like any FECA citizen plaintiff-was essentially attempting to prompt government regulation of someone else, causation and redressability were dispositive "problems." 134

To be sure, the D.C. Circuit's overriding policy concern was that CREW's complaint seemingly amounted to a disagreement "with the Commission's judgment that its resources were better employed on

\footnotetext{
128. Id. at 339 .

129. Citizens for Responsibility \& Ethics in Wash. [CREW] v. FEC, 401 F. Supp. 2d 115, 120 21 (D.D.C. 2005) (quoting Kean for Cong. Comm. v. FEC, 398 F. Supp. 2d 26, 35 (D.D.C. 2005)), aff'd, 475 F.3d 337 (D.C. Cir. 2007).

130. CREW, 475 F.3d at 339 .

131. Id.

132. Id. at 340 .

133. Id.

134. Id.
} 
other, more important matters."135 That court's concern with enabling the judiciary to second-guess quintessentially Article II prerogatives was not new to its particular jurisprudence. ${ }^{136}$ And, of course, it is unquestionably a critical component of the separation of powers. But as the $C R E W$ court acknowledged, ${ }^{137}$ Akins did not undermine this most basic of Article III standing's gate-keeping functions. So the $C R E W$ court did not need to confront the Akins analysis so heavy-handedly in order to justify its dismissal of the complaint on standing grounds.

As discussed below, ${ }^{138}$ the $C R E W$ decision may in part reflect the judges' pragmatic views on the merits of the case; there appeared to be no meaningful campaign or election-related information still to be gained by the lawsuit. To support this aspect of its holding, the D.C. Circuit relied partially on its own dated jurisprudence, dismissing the argument that its 1997 decision in Common Cause "'must yield' to the Supreme Court's later decision in Akins." "139 Indeed, the court flatly retorted that "[t]he short answer is that we have never overruled Common Cause and we have applied its holding and rationale after Akins."140

Although the D.C. Circuit's failure to marry its prior decision with Akins - instead merely noting that Common Cause is still standing in spite of it - is rather remarkable, the Supreme Court could have avoided the doctrinal problem by, first, making clear in Akins that it was reconfiguring (if not partially overruling) Lujan's strict causation and redressability requirements and, second, defining the ambit of the Akins standard. Because it cannot be fully reconciled with the leading public law case on constitutional standing, Akins is at risk of becoming a dead letter, as are the gains to standing law that its groundbreaking analysis

\footnotetext{
135. Id.
}

136. See id. at $341 \mathrm{n} .2$ (citing Am. Soc'y for the Prevention of Cruelty to Animals v. Ringling Bros. \& Barnum \& Bailey Circus, 317 F.3d 334, 337 (D.C. Cir. 2003) (finding standing to sue circus owner under the citizen-suit provision of the ESA because observation of physical manifestations of the alleged mistreatment of elephants "takes [plaintiff's] claim out of the category of a generalized interest in ensuring the enforcement of the law"); Wertheimer v. FEC, 268 F.3d 1070, 1074 (D.C. Cir. 2001) (finding no standing "under the Akins test" because appellants failed to show either that they were being deprived of information or that a favorable ruling would lead to disclosure of information); Judicial Watch, Inc. v. FEC, 180 F.3d 277, 278 (D.C. Cir. 1999) (dismissing FECA complaint for lack of standing because it did not even nominally allege reporting violations)).

137. Id. at 340 ("The Supreme Court in Akins recognized that the Commission, like other Executive agencies, retains prosecutorial discretion." (citing FEC v. Akins, 524 U.S. 11, 25 (1998))).

138. See infra Part IV.B.

139. CREW, 475 F.3d at 341 n.2.

140. Id. at $341 \&$ n.2 (citing Common Cause v. FEC, 108 F.3d 413, 418 (D.C. Cir. 1997) (per curiam) (finding no FECA standing to sue for "information concerning a violation of the Act as such")). 
appeared to foreshadow. ${ }^{141}$ There is simply no safe harbor in which to apply Akins as the law of the case.

\section{ARTICLE II AND THE CONGRESSIONAL GRANT OF FECA STANDING}

It is important to underscore that the D.C. Circuit could have comfortably pointed to the one piece of information that everyone agreed had not been disclosed in $C R E W$ - the value of the list of conservative activists at issue - and declared that standing exists to obtain such information under Akins if the FECA requires its disclosure. The court's quiet defiance of Akins's straightforward holding in this regard signals the $C R E W$ majority's ${ }^{142}$ discomfort with a justiciability jurisprudence that would enable review of Executive decision making on such trivial grounds, without any particularized Lujan-type injury. It reflects a fundamental and polarized policy debate about the proper role of the judiciary in the American tripartite system of government that is epitomized in the doctrinal clash between Lujan and Akins.

This Part explains the competing justiciability theories underlying the two cases and concludes that, its significant merit notwithstanding, the private law model of adjudication upon which Lujan is based is not uniformly tenable; in the FECA context, at least, the public law model has warranted real consideration without meaningful encroachment on Executive prerogatives. Although the FECA's citizen-suit provision enables the judiciary to weigh in on Executive enforcement decisions, that influence is minimal and does not in-and-of-itself justify Lujan's expansive ban on generalized grievances.

\section{A. Executive Accountability and Generalized Grievances}

The injury-in-fact test as epitomized in Lujan is a judicial manifestation of the belief that the case-or-controversy requirement ${ }^{143}$ is "founded in concern about the proper-and properly limited-role of the courts in a democratic society." "144 Federal courts may exercise power "only 'in the last resort, and as a necessity,"” and only when use of the

141. See Sunstein, supra note 10, at 616 (deeming Akins "by far the most important pronouncement on the general issue of standing to obtain information" and discussing its implications).

142. Judge Garland concurred in the judgment on the grounds that "there is no meaningful distinction between this case and Common Cause v. FEC, 108 F.3d 413 (D.C. Cir. 1997)." CREW, 475 F.3d at 341 (Garland, J., concurring).

143. See U.S. CONST. art. III, $\S 2$ (outlining jurisdiction of courts).

144. Warth v. Seldin, 422 U.S. 490, 498 (1975). 
judicial powers is "“consistent with a system of separated powers.",145 Viewed in the light of the respective spheres of influence that define the three branches of government, the standing doctrine assumes that judicial restraint enhances the ability of the executive and legislative branches to function effectively. ${ }^{146}$ In Allen v. Wright, the Court found that minority parents lacked standing to challenge tax deductions to segregated private schools, on the theory that judges would otherwise become "virtually continuing monitors of the wisdom and soundness of Executive action""147 and impinge upon the President's prerogative to "take Care that the Laws be faithfully executed." 148 By this logic, a lawsuit aimed at "restructuring ... the apparatus established by the Executive Branch to fulfill its legal duties" fails to satisfy Article III on Article II separation of powers grounds. ${ }^{149}$

While the Framers' wisdom in precluding citizens from invoking the judiciary to force an agency to reorder its regulatory objectives is transparent, whether Congress can endow that power is trickier. The Supreme Court has wrestled with the question whether Congress can enact a law with a self-contained justiciability grant for decades. ${ }^{150}$ Although accepted in principle, ${ }^{151}$ statutes like the FECA's citizen-suit provision are constitutionally controversial. In keeping with a so-called purely private law model of adjudication, Justice Scalia readily accepts that certain acts of Congress face dormancy or death if the Executive Branch refuses or fails to enforce them, and his Supreme Court opinions reflect this belief. ${ }^{152}$ Adherents to this model eschew legislation that empowers private litigants to engage in enforcement activity, paired with a provision for judicial review, as "end runs" around the Executive. Standing exists under this theory to resolve primarily common-law-like

145. Allen v. Wright, 468 U.S. 737, 751 (1984) (internal citations omitted).

146. See John G. Roberts, Jr., Article III Limits on Statutory Standing, 42 DukE L.J. 1219, 1229 (1993) (advocating strict adherence to the injury-in-fact test).

147. 468 U.S. at 760 (quoting Laird v. Tatum, 408 U.S. 1, 15 (1972)).

148. Id. at 761 (quoting U.S. ConST. art. II, § 3).

149. Id.; see also Sunstein, supra note 5, at 194-95 (discussing the Allen v. Wright opinion in which the Court referred to Article II and separation of powers).

150. See Sunstein, supra note 5, at 193 (discussing the evolution of the congressionally created citizen suit).

151. See supra note 50 and accompanying text (stating that the Supreme Court has recognized congressional power to create justiciable statutory rights).

152. See Hudson P. Henry, A Shift in Citizen Suit Standing Doctrine: Friends of the Earth, Inc. v. Laidlaw Environmental Services, 28 ECOLOGY L.Q. 233, 240-41 (2001) (discussing Justice Scalia's 1983 article, The Doctrine of Standing as an Essential Element of the Separation of Powers, 17 SUFFOLK U. L. REV. 881 (1983)). 
interests, not those of beneficiaries of government regulation. ${ }^{153}$ Justice Scalia makes this argument in his Akins dissent. ${ }^{154}$

Accordingly, in Lujan Justice Scalia described legislation granting and circumscribing agency authority to carry on governmental activities as " "permit[ting] the courts to participate in law enforcement . . only to the extent necessary to protect justiciable individual rights against administrative action fairly beyond the granted powers." 155 By "[i]ndividual rights," Justice Scalia did "not mean public rights that have been legislatively pronounced to belong to each individual who forms part of the public." " ${ }^{56}$ Chief Justice Roberts has similarly explained:

[If] Congress . . . could specify that any person who wants to sue the agency in federal court may do so if he believes the agency is not living up to its mandate[, s]uch a state of affairs would transform the courts into ombudsmen of the administrative bureaucracy, a role for which they are ill-suited both institutionally and as a matter of democratic theory. ${ }^{157}$

Although Justice Scalia's opinion in Lujan accepted the principle that " $[\mathrm{t}]$ he . . . injury required by Art. III may exist solely by virtue of statutes creating legal rights, the invasion of which creates standing,",158 it did so only with the caveat that "in suits against the Government, at least, the concrete injury requirement must remain."159 It is therefore unsurprising that in his Akins dissent, Justice Scalia focused on the nature of the requisite injury: "Particularized' means that 'the injury must affect the plaintiff in a personal and individual way.' If the effect is 'undifferentiated and common to all members of the public,' the plaintiff

153. See Sunstein, supra note 5, at 187-88 (discussing standing in the context of common law).

154. See FEC v. Akins, 524 U.S. 11, 31 (1998) (Scalia, J., dissenting) (stating that if such provisions "were commonplace, the role of the Executive ... would be greatly reduced"). See also Justice Scalia's dissenting opinion in Friends of the Earth, Inc. v. Laidlaw Environmental Services (TOC), Inc., 528 U.S. 167, 198 (2000) (Scalia, J., dissenting), concluding that the majority turned the injury-in-fact requirement into a "sham" by finding that an environmental group had standing to bring a citizen action against a wastewater treatment facility for noncompliance with the limits set by the facility's National Pollutant Discharge Elimination System permit, and his majority opinion in Steel Co. v. Citizens for a Better Environment, 523 U.S. 83, 109-10 (1998), denying standing for a citizen-suit claim under the Emergency Planning and Community Right-To-Know Act.

155. Lujan v. Defenders of Wildlife, 504 U.S. 555, 577 (1992) (quoting Stark v. Wickard, 321 U.S. 288, 309-10 (1944)) (emphasis added).

156. Id. at 578 .

157. Roberts, supra note 146 , at 1232.

158. 504 U.S. at 578 (quoting Warth v. Seldin, 422 U.S. 490, 500 (1975)) (alteration in original) (internal quotation marks omitted).

159. Id. 
has a 'generalized grievance' that must be pursued by political, rather than judicial, means."

This one-size-fits-all understanding of the relationships between the judicial branch and the elected branches of functioning democracy assumes that accountability for agencies "not living up to [their] mandate[s]"161 lies elsewhere. In particular, it assumes that Congress or the President, properly influenced by voters, will wield political pressure on an ineffective agency to get it to do its job, or change the law so as to ensure that endemic problems are remedied.

For his part, Justice Scalia's answer to the problem of agency failure to enforce an Act of Congress is decidedly not to expand private access to the courts, which he views as "restrict[ed] . . . to their assigned role of protecting minority rather than majority interests." 162 He has both asked the rhetorical question: "Does what I have said mean that, so long as no minority interests are affected, 'important legislative purposes, heralded in the halls of Congress, [can be] lost or misdirected in the vast hallways of the federal bureaucracy?" "and answered it: "Of course it does-and a good thing, too," because "[t]he ability to lose or misdirect laws can be said to be one of the prime engines of social change."163 The Supreme Court elsewhere explained it this way: "The assumption that if respondents have no standing to sue, no one would have standing, is not a reason to find standing." 164

Because separation-of-powers concerns implicate not only the proper allocation and preservation of Presidential power-but also that of the legislature and the judiciary-Justice Scalia's response does not adequately address the question raised by the Akins/Lujan dilemma: Can Congress endow citizens with standing to challenge in federal court agency nonenforcement of legislation? The Constitution provides no guidance for determining which laws are enforceable only through the political process. If Congress determines that agency enforcement of its legislative initiatives is inadequate, and that citizens should have access to the courts to prompt enforcement of the law, does the Constitution forbid Congress from legislating standing for that purpose? Under such circumstances, the political solution to underenforcement that the private

\footnotetext{
160. FEC v. Akins, 524 U.S. 11, 35 (1998) (Scalia, J., dissenting) (quoting United States v. Richardson, 418 U.S. 166, 177 (1974) and Lujan, 504 U.S. at 560 \& n.1).

161. Roberts, supra note 146, at 1232.

162. Scalia, supra note 152 , at 895 .

163. Id. at 897 (quoting Calvert Cliffs' Coordinating Comm. v. U.S. Atomic Energy Comm'n, 449 F.2d 1109, 1111 (D.C. Cir. 1971)) (alteration in original).

164. Schlesinger v. Reservists Comm. to Stop the War, 418 U.S. 208, 227 (1974).
} 
law model relies upon-Executive oversight or more and better legislation - is presumably insufficient, at least in the eyes of Congress. Lujan would not nullify citizen-suit legislation under such circumstances, but would stave off litigation absent identification of a plaintiff who can show the requisite individualized harm.

The public law model, by contrast, would unambiguously empower Congress to create causes of action that confer standing on particular plaintiffs without requiring a differentiated showing of injury, ${ }^{165}$ and conceives of the judiciary's role in the separation of powers as integral to ensuring Executive compliance with the law. Accordingly, Justice Blackmun dissented in Lujan because he was "unable to agree with the plurality's analysis of redressability, based as it is on its invitation of executive lawlessness."166 On this theory, the FECA's citizen-suit provision represents an attempt to ensure, through the courts, "the integrity of our electoral process, and, not less, the responsibility of the individual citizen for the successful functioning of that process." 167

Both Lujan and Akins involved challenges to agencies' procedural failures - nonadherence to interagency consultation requirements and the refusal to investigate an alleged campaign finance violation, respectively-pursuant to statutes that authorized citizen suits as means of enforcement. Akins clearly held that Congress has the power to create standing by delineating procedural rights that are enforceable by an undifferentiated citizenry. Although Lujan suggests that self-executing citizen-suit statutes are unconstitutional absent a plaintiff with particularized injury, ${ }^{168}$ Justice Blackmun's dissent expressed a contrary hope that "over time the Court will acknowledge that some classes of procedural duties are so enmeshed with the prevention of a substantive, concrete harm that an individual plaintiff may be able to demonstrate a sufficient likelihood of injury just through the breach of that procedural duty."169

The conflation of the public and the private that Justice Blackmun foresaw has already emerged in some cases, and undermines the practical viability of the private law model. Several examples of procedural harms deemed justiciable by the courts exist. The Freedom of Information Act

165. See generally Henry, supra note 152, at 241 (discussing the public and private law models).

166. Lujan v. Defenders of Wildlife, 504 U.S. 555, 601 (1992) (Blackmun, J., dissenting).

167. United States v. UAW, 352 U.S. 567, 570 (1957); see also Becker v. FEC, 230 F.3d 381, 389 (1st Cir. 2000) (finding that Ralph Nader had standing to sue the FEC "[i]n light of the FECA's concern with ensuring that corporate funds do not undermine the fairness of federal elections").

168. CHEMERINSKY, supra note 17 , at 95 .

169. Lujan, 504 U.S. at 605 (Blackmun, J., dissenting). 
(FOIA), ${ }^{170}$ the most obvious of these, endows an undifferentiated public right to information. Its uncontroversial enforcement by the courts manifests the view that, "as a general matter, the courts owe substantial deference to Congress' substantive purpose in imposing a procedural requirement." 171 The existence of early qui tam suits authorizing private citizens to litigate on behalf of the public, moreover, provides historical evidence that the Supreme Court's individualized injury requirement is out-of-sync with the Constitution. ${ }^{172}$ In an opinion authored by Justice Scalia, the modern Court upheld the federal False Claims Act's qui tam provisions under Article III without a showing that the relator was injured by the alleged fraud. ${ }^{173}$

To be sure, Akins's recognition of the judiciary's statutory prerogative to force the other branches of government to "do their jobs" is circumscribed. A district court prominently refused to read Akins as requiring disclosure of information by Vice President Dick Cheney to the Comptroller General, for example, regarding meetings of his national energy task force in Walker $v$. Cheney. ${ }^{174}$ The pertinent statute allows the Comptroller General to enforce statutory investigatory powers by bringing a civil action to require agency heads to produce records. ${ }^{175}$ The court declined to construe the legislative grant of enforcement power as authorizing suit by the Comptroller General because to do so would "affect[] the balance of power between the Article I and Article II Branches." Although nominally a standing decision, the court was

170. 5 U.S.C. $\S 552(2000)$

171. Lujan, 504 U.S. at 606 (Blackmun, J., dissenting). Professor Cass Sunstein maintains, accordingly, that "[a]n injury in fact . . . is neither a necessary nor a sufficient condition for standing" because "[w]hether a plaintiff has standing depends on what the relevant statute says." Sunstein, supra note 10, at 639, 637-38; see also Fletcher, supra note 62, at 253-54 (arguing that the Court acts improperly in denying standing where Congress explicitly conferred it).

172. See Morrison, supra note 68 , at $626 \&$ n. 168 (collecting articles).

173. See Vt. Agency of Natural Res. v. United States ex rel. Stevens, 529 U.S. 765, 774 (2000) (finding that the "United States' injury in fact suffices to confer standing" on the relator). In Vermont Agency of Natural Resources, Justice Scalia rejected the argument that the statutory monetary rewards provided to the private-party relator if the complaint results in money damages to the government are sufficient to confer standing, since that interest does not "consist of obtaining compensation for, or preventing, the violation of a legally protected right." Id. at 772-73. Instead, he grounded standing for qui tam relators on the "doctrine that the assignee of a claim has standing to assert the injury in fact suffered by the assignor." Id. at 773. Professor Sunstein has also advocated legislation that includes bounties to prevailing plaintiffs for purposes of satisfying the injury-in-fact standard as it exists. Sunstein, supra note 5, at 168.

174. See 230 F. Supp. 2d 51, 66 n.10 (D.D.C. 2002) (distinguishing Akins by noting that the lawsuit was brought "by private parties, not government officials, and thus involved injuries in which the plaintiffs ... had only a personal stake").

175. 31 U.S.C. $\S 716(b)(2)(2000)$.

176. Walker, 230 F. Supp. 2d at 69-70. 
fundamentally troubled by the separation of powers implications of the statute itself. ${ }^{177}$ The Vice President argued that "Congress cannot, consistent with separation of powers principles, endow the Comptroller General with the authority to bring this judicial action."178 Although the dispute involved Congress's attempt to enforce its own rights to Executive Branch information, ${ }^{179}$ the court's view rested on the same theory underlying Justice Scalia's dissent in Akins - that the role of the courts is to protect "the constitutional rights and liberties of individual citizens and minority groups against oppressive or discriminatory government action." $" 180$

The Cheney decision is consistent with the thrust of Lujan standing jurisprudence that virtually forecloses the generic citizen from seeking to remedy general complaints about how the Executive Branch is operating. In this respect, "informational standing"-or standing to obtain information a statute makes public - is a rarity. ${ }^{181}$ Although Akins represents a shift in the majority of the then-current Justices' thinking toward allowing Congress to authorize citizens to bring lawsuits enforcing government regulations, the Court is by no means ready to dispense with the injury-in-fact requirement. ${ }^{182}$ The Lujan Court's separation-of-powers stance that "[v]indicating the public interest (including the public interest in Government observance of the Constitution and laws) is the function of Congress and the Chief

177. See id. at 59 (discussing merits)

178. Id. at 60

179. See id. at 71 (discussing the Comptroller General's arguments as to why Congress has the right to the Executive Branch information).

180. Id. at 72 (citing United States v. Richardson, 418 U.S. 166, 192 (1974) (Powell, J., concurring)). Implicit in another case, United States House of Representatives v. United States Department of Commerce, 11 F. Supp. 2 d 76 (D.D.C. 1998), is the opposing viewpoint. The court found that the House of Representatives had Article III standing to sue the Commerce Department and the Census Bureau challenging their plan to use statistical sampling in the upcoming census because the alleged failure to use the statutorily required methodology was an "informational and compositional injur[y]." Id. at 91.

181. See Chamber of Commerce of the U.S. v. FEC, 69 F.3d 600, 603 (D.C. Cir. 1995) ("This statute is unusual in that it permits a private party to challenge the FEC's decision not to enforce."). But cf. Friends of the Earth, Inc. v. Laidlaw Envtl. Servs. (TOC), Inc., 528 U.S. 167, 198-215 (2000) (Scalia, J., dissenting) (addressing citizen-suit provision in Water Act); supra note 33 and accompanying text (listing a handful of federal statutes expressly conferring standing on "any person," "citizen," or "party" to challenge agency actions).

182. Henry, supra note 152, at 249; see also Lance v. Coffman, 127 S. Ct. 1194, 1198 (per curiam) (finding that Colorado citizens lacked standing to bring a challenge under the Elections Clause of the U.S. Constitution because "[t]he only injury plaintiffs allege is that the law . . . has not been followed [which] is precisely the kind of undifferentiated, generalized grievance about the conduct of government that we have refused to countenance in the past"). But $c f$. Massachusetts v. EPA, 127 S. Ct. 1438, 1453-56 (2007) (adopting Akins analysis to find that State has standing to sue the EPA to force rulemaking concerning widely-shared global warming risks). 
Executive" is unassailable at the margins. ${ }^{183}$ The barrier to adjudicating generalized grievances properly prevents the pure ideologue from suing over distaste with how the government is operating. ${ }^{184}$ Given the myriad problems with the injury-in-fact test as we know it, what is less evident is whether the Court's endowment of the Lujan standard with "separationof-powers significance" properly keeps the judiciary out of the business of vindicating the public interest. ${ }^{185}$

\section{B. The Case of the FEC: Circularity and Conundrum}

As Justice Stevens noted in his Lujan concurrence, "[w]e must presume that if this Court holds that [the ESA] requires consultation, all affected agencies would abide by that interpretation," as "[c]ertainly the Executive Branch cannot be heard to argue that an authoritative construction of the governing statute by this Court may simply be ignored by an agency head."186 An adherent to the private law model might be comfortable resting on faith that the Executive will consistently choose to follow the law for fear of political reprisal. If Jane Doe's frustration with the federal government's budget failures is insufficiently concrete to trigger the jurisdiction of an Article III court, she need only cast her votes in protest or, failing that, lobby her congressional representatives for reform. The harshness that, on certain facts, Lujan's injury-in-fact standard produces is palatable to some only because the political branches are positioned to handle generalized grievances.

A citizen-suit statute challenges this view of the separation of powers by enabling outsiders to invoke the judiciary to enhance traditional Executive enforcement mechanisms in a statutory arena of particular congressional concern. Although Congress sets the parameters for Executive enforcement action by passing the laws to be enforced, the Constitution does not expressly enable or preclude the legislation of private citizens' access to the courts to bring about enforcement activity. ${ }^{187}$ Democratic theory aside, the separation of powers concerns

\footnotetext{
183. Lujan v. Defenders of Wildlife, 504 U.S. 555, 576 (1992).

184. CHEMERINSKY, supra note 17 , at 96.

185. 504 U.S. at 577.

186. Id. at 585 (Stevens, J., concurring).

187. Congress has broad power under the Necessary and Proper Clause of the Constitution to pass legislation to redress social, economic, and other problems the legislature identifies as important. U.S. CONST. art. I, § 8, cl. 18; see also M'Culloch v. Maryland, 17 U.S. (4 Wheat.) 316, 323-26 (1819) (examining Congress's role in determining what is "necessary and proper"). The dimensions of that power under the text and history of the Constitution is an issue that is beyond the scope of this Article.
} 
that underlie a pure private law model of adjudication are somewhat alleviated empirically by the fact that Congress's invocation of its perceived power to endow citizens with the right to sue to enforce legislation is hardly ubiquitous. ${ }^{188}$ It is thus fair to assume that political accountability is sufficient for ensuring that the laws are properly enforced in most instances.

If the private law model correctly assumes that politics suffice to ensure Executive accountability in all areas of congressional and public concern, the question arises as to whether the FECA's citizen suit (and Akins's substantiation of it) is justifiable at all. This subpart considers that question and concludes that, in light of the widespread but disparate criticism of the FEC's effectiveness, the FECA's circumscribed citizensuit provision is a reasonable exercise of Congress's power to "legislate" this type of standing.

The FECA's citizen-suit provision was added as an amendment to the original bill and is described in the legislative history as "the one provision . . . that will enable the public to get a better look at the investigative process to be used against suspected violators of the law." 189 The sparse legislative history suggests that the provision was at its inception and has since been uncontroversial in the Congress. The 1976 amendments allowed "any person," including a member or employee of the FEC, to file a verified (versus anonymous) administrative complaint. ${ }^{190}$ In the floor debate over the 1979 amendments, one member explained:

The Commission is entrusted with the responsibility of passing on complaints. [The citizen-suit provision] provides that an order dismissing a complaint is reviewable in court solely to assure that the Commission's action is not based on an error of law. And to assure that the Commission does not shirk its responsibility to decide that section also provides that a total failure to address a complaint within 120 days is a basis for a court action. ${ }^{191}$

\footnotetext{
188. See supra note 33 and accompanying text.

189. S. REP. No. 92-229, at 110 (1971), reprinted in 1972 U.S.C.C.A.N. 1821, 1848.

190. H.R. REP. No. 94-1057, at 50 (1976) (Conf. Rep.).

191. 125 Cong. ReC. 36,744, 36,754 (1979) (statement of Sen. Pell). Senator Pell goes on to

these two limited bases for judicial intervention are not intended to work a transfer of prosecutorial discretion from the Commission to the courts. Thus, for example, if the Commission considers a case and is evenly divided as to whether to proceed, that division which under the act precludes Commission action on the merits is not subject to review any more than a similar prosecutorial decision by a U.S. attorney.

Id. The current statute does not include a carve-out to preclude review of a tie vote by the
} state 
Whether the speaker's concern with the Commission "shirk[ing] its responsibility" is valid remains a sharply debated question. Critics disagree over whether the FEC is too lax or too stringent in enforcing the law, both sides arguing that-for very opposite reasons - the current system is flawed in one way or another. ${ }^{192}$

The FEC was created in 1974 for purposes of administering and enforcing the federal campaign finance laws and is reputed to be a "toothless tiger" amongst some critics. ${ }^{193}$ By virtue of its structure, critics contend, the Commission is inherently conflicted in terms of the vigor with which it can reasonably be expected to enforce the terms of the FECA against politicians, their parties, and their affiliates. ${ }^{194}$ The FEC comprises six politicized members, three from each party, and a deadlocked vote kills an enforcement action. ${ }^{195}$ The 1974 statute creating the agency empowered Congress to appoint four of the six commissioners with the President choosing the other two, ${ }^{196}$ but the Supreme Court struck down this system in Buckley v. Valeo on the grounds that it violated the President's appointment authority under Article II of the Constitution. ${ }^{197}$ Congress amended the FECA in 1976 to shift the appointment power entirely to the President on confirmation by the Senate, ${ }^{198}$ but it is said to be "common knowledge" that congressional party leaders have continued to exercise considerable power over the

Commission, which would make little sense in any event. A 3-3 vote is effectively a decision not to take enforcement action, although a majority did not so find. A 4-3 vote not to take enforcement action, by contrast, implies that commissioners from both sides of the political aisle agree to stand down on a complaint.

192. See generally Todd Lochner, Overdeterrence, Underdeterrence, and a (Half-Hearted) Call for a Scarlet Letter Approach to Deterring Campaign Finance Violations, 2 ELECTION L.J. 23 (2003) (addressing both critiques and suggesting a public shaming approach to campaign finance violators).

193. E.g., Amanda S. La Forge, Comment, The Toothless Tiger-Structural, Political and Legal Barriers to Effective FEC Enforcement: An Overview and Recommendations, 10 ADMIN. L.J. 351, 358-73 (1996); Bill McAllister, FEC Admits Failures in Plea for Funding: Agency Outlines Wide Probe of '96 Campaign, WASH. Post, Jan. 31, 1997, at A8. See generally ProJECT FEC, No BARK, No Bite, No Point: The Case for Closing the Federal Election Commission and ESTABLISHING A NEW SYSTEM FOR ENFORCING THE NATION's CAMPAIGN FINANCE LAWS 5 (2002) (arguing the Commission's structure prevents it from being effective).

194. See, e.g., La Forge, supra note 193, at 365 ("[T] he FEC finds itself in the unique position of regulating the very people who control its annual budget."); McAllister, supra note 193 (reporting on the FEC's admission that it had "failed to move swiftly against politicians who violate campign finance laws"). See generally PROJECT FEC, supra note 193 (advocating dissolution of the FEC and the establishment of a new means to enforce campaign finance laws).

195. See 2 U.S.C. $§ 437$ c (2000) (describing structure of FEC).

196. Federal Election Campaign Act Amendments of 1974, Pub. L. No. 93-443, § 310(a)(1), 88 Stat. 1263, 1280-81, declared unconstitutional by Buckley v. Valeo, 424 U.S. 1 (1976).

197. 424 U.S. at 132-36 (per curiam); PROJECT FEC, supra note 193, at 15.

198. Federal Election Campaign Act Amendments of 1976, Pub. L. No. 94-283, § 101(a)(1), 90 Stat. 475,475 . 
appointment process. ${ }^{199}$ As a result, the choice of commissioners can rest on political affiliations rather than expertise. ${ }^{200}$ In overseeing an agency whose mission is to oversee members of Congress, Congress has been accused of underfunding the FEC, launching intrusive audits, and otherwise hobbling its regulator. ${ }^{201}$ Numerous courts have derided the FEC as having historically taken "a permissive view" of the campaign laws. ${ }^{202}$

This portrait of the "FEC-as-lapdog" of the politicians is strongly disputed, with other scholars depicting a very different agency that is not only competent and adaptable, but guilty of overenforcement of the campaign finance and election laws in excess of the Commission's constitutional and statutory authority. ${ }^{203}$ There is purportedly "widespread belief" amongst the practicing bar that the FEC goes after minor players to affect legal behavior by intimidation, ${ }^{204}$ and courts have repeatedly struck down the FEC's construction of the FECA as vastly overreaching. ${ }^{205}$ Whether guilty of underenforcement or overenforcement, then, the FEC is a reasonably susceptible target for

199. PROJECT FEC, supra note 193, at 16 (citing Jackie Koszczuk, Money Woes Leave FEC Watchdog with More Bark Than Bite, 56 CoNG. Q. 469, 469 (1998); Peter H. Stone, Teaching a Lapdog to Bite, 25 NAT'L J. 2914, 2914 (1993); Tim Curran, Secretary of Senate Gets Official Nod by the President to Become Member of the Federal Election Commission, Roll CALL, Sept. 30, 1996).

200. Id. at 15-18, 60-65. Former FEC Commissioner Frank Reiche has explained that members of Congress "view the members of the commission as representatives of their party-you can't have a successful campaign finance commission if that is the premise upon which appointments are made." Deirdre Davidson, Who's Afraid of the FEC?: Why the FEC Doesn't Have Any Weight to Throw Around, TOMPAINE.COM, Oct. 3, 2000, http://www.tompaine.com/Archive/scontent/ 3700.html.

201. PROJECT FEC, supra note 193, at 19.

202. Shays v. FEC, 414 F.3d 76, 81, 106 (D.C. Cir. 2005) (stating also that FEC rules "fly in the face" of the enabling statute's purpose, and noting the "absurdity" of the FEC's position); see also, e.g., McConnell v. FEC, 540 U.S. 93, 142 (2003) (finding that FEC had "subverted" federal election campaign laws); Shays v. FEC, 337 F. Supp. 2d 28, 63, 70, 79 (D.D.C. 2004) (finding that challenged FEC regulation would "undercut[] FECA's statutory purpose" and "foster corruption," and observing that the challenged FEC regulation would "render the statute largely meaningless"), aff'd, 414 F.3d 76.

203. Bradley A. Smith \& Stephen M. Hoersting, A Toothless Anaconda: Innovation, Impotence and Overenforcement at the Federal Election Commission, 1 ELECTION L.J. 145, 162-63 (2002). For a point-by-point response to the arguments underlying the view that the FEC is a meek enforcement agency, see Bradley A. Smith, Campaign Finance Reform: What Congress and the FEC Should Do Next, 1881 P.L.I. CORP. 347, 350-55 (2002).

204. Smith \& Hoersting, supra note 203, at 156.

205. Id. at 162-69 (discussing cases); see also, e.g., FEC v. Christian Action Network, Inc., 110 F.3d 1049, 1050 (4th Cir. 1997) (holding that FEC's position that advocacy organization's expenditures for television commercial violated federal election laws governing disclosure of campaign funds lacked substantial justification under the Equal Access to Justice Act). 
third party enforcement mechanisms such as the FECA's citizen-suit provision.

Additionally, it is important to keep in mind that the scope of the FECA's citizen-suit provision is relatively narrow. On balance, Congress was not overreaching in allowing judicial review of certain nonenforcement decisions. The FEC does rely on outside complaints in some measure to carry out its statutory mandate. Although FECA enforcement proceedings germinate either internally from FEC investigators or externally from third-party complaints, ${ }^{206}$ a 1999 study of approximately eighty FEC matters under review (also known as "MURs") revealed that a heavy proportion-sixty-three percent-were initiated by outside parties, ${ }^{207}$ who were more likely to target campaigns and candidates ${ }^{208}$ and to allege disclosure violations - as in Akins - than so-called "substantive" FECA violations, such as excessive contributions or the use of prohibited funds. ${ }^{209}$ The universe of claims that potentially trigger the FECA's citizen-suit provision is comprised exclusively of those that are dismissed prior to investigation and those for which the Commission failed to timely take any action whatsoever. ${ }^{210}$ About thirty-two percent of the sample claims were dismissed preinvestigation, and eighty-eight percent of those were brought by third parties. ${ }^{211}$

Given that a majority of the dismissed sample complaints were brought by outside parties, scholars have posited that a large portion of third-party complaints may amount to frivolous gamesmanship aimed at

206. The FEC is an independent agency with exclusive jurisdiction over enforcement of the FECA. 2 U.S.C. $\S \S 437 \mathrm{c}(\mathrm{b})(1), 437 \mathrm{~d}(\mathrm{a})(3), 437 \mathrm{~g}$ (2000). The Commission is authorized to institute investigations of possible FECA violations and "any person" may file a sworn administrative complaint alleging a violation of the Act. $I d$. $\S 437 \mathrm{~g}(\mathrm{a})(1)-(2)$. Upon receipt of a complaint and any response, the FEC's General Counsel usually forwards a recommendation to the Commission as to whether there is "reason to believe" or "RTB" that a violation of the Act has occurred, and the Commission votes. Id. If four or more members find RTB, the FEC commences an investigation. Id. After the investigation, the full Commission votes again, this time to determine if there is "probable cause" to believe the FECA has been violated. Id. $\$ 437 \mathrm{~g}(\mathrm{a})(4)(\mathrm{A})(\mathrm{i})$. If a majority finds probable cause, the FEC will attempt to reach a conciliation agreement. Id. In the absence of such an agreement, the Commission can vote to institute a de novo civil enforcement action. Id. $\S$ $437 \mathrm{~g}(\mathrm{a})(6)(\mathrm{A})$. At any point in the process, a tie vote will lead to dismissal of the complaint. See Common Cause v. FEC, 108 F.3d 413, 415 (D.C. Cir. 1997) (per curiam) (discussing facts where a deadlocked Commission led to dismissal of a complaint).

207. Todd Lochner \& Bruce E. Cain, Equity and Efficacy in the Enforcement of Campaign Finance Laws, 77 TEX. L. REV. 1891, 1910, 1927 (1999).

208. Id. at 1912.

209. Id. at 1913.

210. See 2 U.S.C. $\S 437 \mathrm{~g}(\mathrm{a})(8)(\mathrm{A})$ (providing that "[a]ny party aggrieved by an order of the Commission dismissing a complaint filed by such party [with the FEC], or by a failure of the Commission to act on such complaint during the 120-day period beginning on the date the complaint is filed, may file a petition with the United States District Court for the District of Columbia").

211. Lochner \& Cain, supra note 207, at 1916, 1920. 


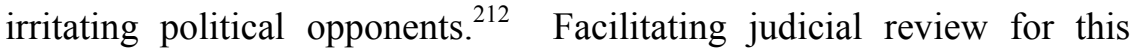
group of claimants might exacerbate any wasted resources problem that already exists. But the protracted administrative process for disposing of these claims - with most taking a minimum of eleven months to conclude - undermines the deterrent value of enforcement within any particular campaign cycle. ${ }^{213}$ To the extent third parties do file administrative complaints simply to anger an opponent, their incentive to expend the resources to challenge a dismissal in court one or two years later-postelection-seems diminutive, as evidenced by the mere handful of cases involving citizen-suit complaints. ${ }^{214}$ The goal of winning an election may justify law-breaking and the attendant penalties, which are internalized as a cost of doing business. ${ }^{215}$ As the adverse publicity caused by the filing of an administrative complaint is not considered a formidable deterrent for election law violators, ${ }^{216}$ the purportedly large percentage of third-party complaints that end in dismissal has not translated into a flood of FECA citizen-suit litigation.

If the dismissed claims that wind up in court do predominantly involve the FECA's disclosure provisions, they may constitute an appropriate subgroup of claims for which the extraordinary third-party enforcement measure should apply. Public opinion favors election and campaign finance laws. ${ }^{217}$ The Supreme Court has noted "a profound national commitment to the principle that debate on public issues should be uninhibited, robust, and wide-open," 218 and, applying this principle to disclosure provisions, has stated that "disclosure requirements deter

212. Id. at 1904,1920 .

213. Id. at $1929,1932$.

214. A review of the FEC's website identifies fifty-seven FECA cases filed in federal court between 2001 and 2006. Alphabetical Index of FEC Court Cases, http://www.fec.gov/law/ litigationalpha.shtml (last visited Mar. 9, 2007). Ten of these were citizen suits brought pursuant to 2 U.S.C. $\S 437 \mathrm{~g}(\mathrm{a})(8)$. Hagelin v. FEC, 411 F.3d 237 (D.C. Cir. 2005); Citizens for Responsibility \& Ethics in Wash. v. FEC, 401 F. Supp. 2d 115 (D.D.C. 2005), aff'd, 475 F.3d 337; Alliance for Democracy v. FEC, 362 F. Supp. 2d 138 (D.D.C. 2005); Judicial Watch v. FEC, No. Civ.A. 011747, 2005 WL 433344 (D.D.C. Feb. 17, 2005); Kean for Cong. Comm. v. FEC, 398 F. Supp. 2 d 26 (D.D.C. 2005); Alliance for Democracy v. FEC, 335 F. Supp. 2d 39 (D.D.C. 2004); Bush-Cheney '04, Inc. v. FEC, No. 04CV01501 (D.D.C. filed Sept. 1, 2004); Akins v. FEC, No. 03CV02431 (D.D.C. filed Nov. 25, 2003); Judicial Watch v. FEC, 293 F. Supp. 2d 41 (D.D.C. 2003); Common Cause v. FEC, No. 01CV02423 (D.D.C. filed Nov. 21, 2001). A Westlaw search revealed an additional citizen-suit case, Tierney v. FEC, No. 1:06CV00663, 2006 WL 1344027 (D.D.C. Apr. 11, 2006). Together, these eleven cases comprise roughly nineteen percent of all FECA cases filed from 2001 to 2006

215. Lochner \& Cain, supra note 207, at 1930.

216. Id. at 1919.

217. Lauren Eber, Waiting for Watergate: The Long Road to FEC Reform, 79 S. CAL. L. REV. 1155,1158 (2006).

218. N.Y. Times Co. v. Sullivan, 376 U.S. 254, 270 (1964). 
actual corruption and avoid the appearance of corruption by exposing large ... expenditures to the light of publicity." 219 Disclosure educates voters $^{220}$ and prevents circumvention of other aspects of the federal election laws. ${ }^{21}$ The Court has gone so far as to characterize the disclosure provisions as constitutionally moored - "a reasonable and minimally restrictive method of furthering First Amendment values."222

Moreover, disclosure may occupy a uniquely useful role in election and campaign finance regulation and in deterring would-be violators. Although the FEC's critics disagree over the nature and source of the enforcement problem, two points seem uncontroversial. First, the current regulatory enforcement scheme-which relies upon relatively trivial and untimely administrative or civil fines - is ineffective and, second, the reasons for its ineffectiveness include one that is intractable: First Amendment limitations on enjoining pre-election political speech. ${ }^{223}$ Some have therefore suggested that "an emphasis on disclosure and enforcement by "information"" is a uniquely viable solution to the problem. $^{224}$ If third-party complaints do, in fact, disproportionately raise disclosure violations, third-party enforcement would enhance the agency's ability to effectively carry out a core aspect of its mission. ${ }^{225}$

As for the overenforcement critique of the FEC, vigorous standing challenges by the Commission are an inapposite fix. The FEC is simultaneously assailed for weak enforcement and for "look[ing]

219. Buckley v. Valeo, 424 U.S. 1, 67 (1976).

220. See Nichol, supra note 59, at 334 ("Other rulings" by the Supreme Court "have [also] . . been thought to bolster democratic participation rather than to thwart it," e.g., "it makes little sense to say that traditional victims of discrimination or those who have been effectively shut out of democratic processes ought to be relegated to asserting their most fundamental rights only through electoral politics.").

221. See FEC v. Beaumont, 539 U.S. 146, 155 (2003) (discussing regulation of corporate electoral involvement and use of organizations as conduits for circumvention of contribution limits); Buckley, 424 U.S. at 67-68 (stating that disclosure requirements are an essential means of gathering data necessary to detect contribution limit violations and the evils of campaign corruption).

222. Buckley, 424 U.S. at 82; see also, e.g., First Nat'l Bank of Boston v. Bellotti, 435 U.S. 765, 792 n.32 (1978) (discussing that identification of the source of advertising may be required). But here again, there is legitimate debate. Although disclosure informs voters, it comes at the cost of hindering anonymous political speech. Smith, supra note 203, at 361-62 (citing McIntyre v. Ohio Elections Comm'n, 514 U.S. 334 (1995)).

223. See, e.g., Bradley A. Smith, McConnell v. Federal Election Commission: Ideology Trumps Reality, Pragmatism, 3 ELECTION L.J. 345, 350-51 (discussing the tension between the "appearance of corruption" rationale for legislation limiting political speech and the infringements on First Amendment rights)

224. Lochner \& Cain, supra note 207, at 1892, 1935-36.

225. Citizen standing to obtain judicial review of the Commission's nonenforcement decisions also serves to counteract perceived political bias on the part of the FEC in its enforcement process. See id. at 1894 (explaining that many critics of the FEC suggest that the FEC fails in its enforcement because it is biased toward the party controlling Congress). 
everywhere" to expand the scope of its investigations to capture bit players. $^{226}$ Small grassroots organizations lack the expertise and capital to readily comply with the FECA's onerous disclosure provisions and may be disproportionately "chill[ed]" in their legal activities for fear of FEC scrutiny. ${ }^{227}$ But the limited research that exists does not suggest that the citizen-suit provision worsens the problems identified with FECA enforcement. Although the FECA's citizen-suit provision reflects an unambiguous legislative objective to shift some measure of power and control over its enforcement to private citizens via access to the judiciary, it impacts a narrow range of cases and is poised only to marginally disturb the agency's prerogative to enforce the law. As a test case for considering the relative merits of the private and public law models of adjudication, therefore, Congress's circumscribed mechanism for ensuring that the FEC does not shirk its enforcement responsibilities comfortably warrants the Court's constitutional approval in Akins.

\section{TOWARD A NEW JUSTICIABILITY PARADIGM: FECA STANDING AND BEYOND}

With the specter of excessive judicial interference under $\S 437 \mathrm{~g}(\mathrm{a})(8)$ dispelled, this Part attempts to reconcile Lujan and Akins and the polarized theories of adjudication at play. Courts should, as a matter of sound justiciability jurisprudence, honor congressional intent and Akins's clear holding by affording information-seeking plaintiffs standing per se under the FECA's citizen-suit provision. Although the broader implications of Akins have not been fully realized, this Part attempts to justify modest expansion of its premises.

Despite the rigidity of Lujan's injury-in-fact test, the Supreme Court has already retracted from the causation and redressability requirements in cases implicating the enforcement of public rights. As this Part observes, this doctrinal development is sensible. Because the standards for substantive review of the Executive's nonenforcement decisions are deferential, the separation-of-powers concerns underlying the private law model of adjudication are satisfied at the merits stage of the litigation in

226. Smith, supra note 203 , at 356-57.

227. Id. Although this Article proposes that courts adopt a FOIA-like perspective that would treat FECA citizen-suit standing as virtually automatic, whether citizen standing should be expanded to capture overenforcement practices or whether it exacerbates the perceived intimidation of small groups as it stands is another matter. Further research is necessary to determine empirically whether meritless complaints against tangential violators, dismissed by the FEC, end up in citizen-suit litigation to an unacceptable degree or, more importantly, whether the threat of litigation worsens the effects of enforcement on remote actors engaging in legitimate activities. 
FECA cases. An Akins approach to standing that focuses on statutory injury without requiring strict causation and redressability would create incentives for agency compliance with the law by affording more merits scrutiny.

\section{A. Per Se FECA Standing and the Emerging Irrelevance of Causation and Redressability}

As described in Part II, Akins collides with Lujan on causation and redressability when the facts are such that it appears "entirely conjectural whether the nonagency activity that affects [plaintiffs] will be altered or affected by the agency activity they seek to achieve." 228 These words, authored by Justice Scalia, articulate a standard that would render standing virtually impossible to satisfy in cases involving something other than direct regulation of the plaintiff, such as, for example, the denial of a pollution permit. In Akins, it was "entirely conjectural" whether AIPAC would produce information in response to the hypothetical FEC enforcement action the plaintiffs sought. For that matter, it was conjectural whether the FEC would order AIPAC to turn over the information after investigating the allegations on remand. Yet a majority of the Court found standing. In public law cases brought to enforce a "right" or to "right a wrong" that is undifferentiated amongst the public, Akins renders the Lujan formulation of causation and redressability obsolete.

Accordingly, in informational cases under Akins, a lack of information that must be disclosed under the statute should be per se sufficient injury, much as it is well-established that "[a] person seeking information under the FOIA . . . need not have a personal stake in the information sought" to bring suit. ${ }^{229}$ The filing of a FOIA request and its denial is sufficient "harm" to distinguish the plaintiff from the general populace for Article III purposes. ${ }^{230}$ Under Lujan, one could argue that

228. Lujan v. Defenders of Wildlife, 504 U.S. 555, 571 (1992) (plurality opinion).

229. McDonnell v. United States, 4 F.3d 1227, 1237-38 (3d Cir. 1993).

230. United States v. Richardson, 418 U.S. 166, 204 (1974) (Stewart, J., dissenting) (citing 5 U.S.C. § 552(a)(3)); McDonnell, 4 F.3d at 1238. The Supreme Court has long recognized that no showing of need for specific information is necessary to invoke the jurisdiction of the federal courts as a matter of constitutional law. It is well-established that even though a FOIA plaintiff's injury-a lack of information - is shared generally, the generalized nature of that grievance is not a constitutional barrier to standing. Pub. Citizen v. U.S. Dep't of Justice, 491 U.S. 440, 449 (1989) (citing U.S. Dep't of Justice v. Reporters Comm. for Freedom of the Press, 489 U.S. 749 (1989); U.S. Dep't of Justice v. Julian, 486 U.S. 1 (1988); United States v. Weber Aircraft Corp., 465 U.S. 792 (1984); FBI v. Abramson, 456 U.S. 615 (1982); Dep’t of Air Force v. Rose, 425 U.S. 352 (1976)). 
the absence of information sought by a FOIA request, without more, is too generalized and lacking in particularity to be cognizable, and that many FOIA requesters' transparent aim to pry into the workings of the government and bring lawsuits to impact administrative enforcement activity dispels any notion of legitimate need. ${ }^{231}$ But the horribles expected to flow from an overbearing judiciary in the citizen-suit arena have not occurred with FOIA litigation. Aside from delays in administrative processing, the statute seems to work; one searches in vain for lower-court decisions addressing standing to bring a FOIA case. Once in court, the cases go right to the merits, without long and expensive preliminary litigation to divine injury within the meaning of conflicting Supreme Court case law. Indeed, FECA litigation gives credence to the notion that if standing hearings were routine in the FOIA context, "[a]gencies reluctant to disclose information would have a powerful incentive both to stall and to find that the requester does not have standing." 232

The Supreme Court found "no reason for a different rule" under the Federal Advisory Commission Act (FACA), ${ }^{233}$ which stipulates that minutes, records, and reports of Executive Branch advisory committees be made available to the public, so long as they do not fall within one of the FOIA's disclosure exemptions. ${ }^{234}$ In a challenge by a public interest group to the Department of Justice's refusal to divulge the names of potential judicial nominees submitted to a committee of the American Bar Association, the Court rejected the argument that a plaintiff's attempt to seek access to such information was a nonjusticiable "general grievance," citing the FOIA as authority. ${ }^{235}$

Like the FOIA and the FACA, which "specifically provide for and are intended to promote 'disclosure and public access' to the workings of government and a policy of 'government in the sunshine,",236 the FECA promotes the goals of disclosure and public access that justified the

231. See Richard J. Pierce, Jr., Lujan v. Defenders of Wildlife: Standing as a Judicially Imposed Limit on Legislative Power, 42 DUKE L.J. 1170, 1189 (1993) ("Perhaps [the] interest is derivative of the general public's interest in knowing what the government is doing. If so, that would seem to be an 'undifferentiated public interest' that Congress cannot convert 'into an "individual right" vindicable in the courts." (quoting Lujan, 504 U.S. at 577)).

232. Id. at 1190; see also Mark Tushnet, "Meet the New Boss": The New Judicial Center, 83 N.C. L. REV. 1205, 1213-14 n.40 (2005) (observing that the "impairment of public access" to information as an injury sufficient to confer standing in the ordinary FOIA case goes unquestioned).

233. Pub. Citizen, 491 U.S. at 449.

234. 5 U.S.C. app. $\S 10(\mathrm{a})(2)$, (d) (2000).

235. Pub. Citizen, 491 U.S. at $448-50$.

236. Am. Farm Bureau v. U.S. EPA, 121 F. Supp. 2d 84, 98 (D.D.C. 2000). 
Supreme Court's straightforward standing jurisprudence elsewhere. ${ }^{237}$ If voters have more complete information under the FECA, and their votes are in fact influenced by information regarding the source of a candidate's money or how it is spent, candidates may become mindful of compliance in a way that they are not now, precisely because the outcome of the election - rather than modest after-the-fact fines - could be affected. ${ }^{238}$ If candidates know who is funding their opponents, they also can more fairly respond.

Resolution of standing disputes in cases seeking election-related information under the FECA's citizen-suit provision should, like FOIA and FECA cases, be facile and uncontroversial. Courts should deny motions to dismiss for lack of standing in such cases sua sponte and order the FEC to pay the plaintiff's fees and costs. The frontier of standing litigation in public law cases could then properly shift to whether to apply Akins in lieu of Lujan in noninformational citizen suits, not whether Akins applies at all. ${ }^{239}$

But what, then, is left of Lujan standing in cases brought under citizen-suit statutes if Akins is taken to its logical extreme? Congress's ability to create a justiciable "right" to information does not mean that any government activity is open to judicial scrutiny on the theory that it informs voters. Akins did not overrule the separation of powers principle that courts are not constitutionally authorized to second-guess policy decisions by the elected branches. On this question, Justice Kennedy's concurrence in Lujan is revealing. In accepting the controversial proposition that Congress does have the power to define novel injuries that will give rise to a case or controversy, he observed that, "[i]n exercising this power ... Congress must at the very least identify the injury it seeks to vindicate and relate the injury to the class of persons

237. See supra notes 229-36 and accompanying text (discussing FOIA and FACA standing).

238. Whether the election and campaign finance laws in fact operate to make the system more fair is another debater's point that is outside the scope of this Article. Cf. Bradley A. Smith, Campaign Finance Reform: Searching for Corruption in All the Wrong Places, 2002-2003 CATO SUP. CT. REV. 187, 197-201 (2003) (challenging the assumption that limitations on campaign contributions inhibit corruption).

239. There is a large body of standing law and scholarship that has developed with respect to environmental litigation in particular. See generally, e.g., Adrienne Smith, Standing and the National Environmental Policy Act: Where Substance, Procedure, and Information Collide, 85 B.U. L. REV. 633, 653-62 (2005) (arguing that standing law should allow plaintiffs to sue under NEPA on an informational theory). This Article does not address the application of Akins to environmental cases, although the majority of citizen-suit statutes do appear in that context. See supra note 33 . The thesis of this Article is, rather, that Akins should be brought to the forefront of standing litigation in analogous circumstances instead of dismissing it as confined to voter suits for information under the FECA. 
entitled to bring suit." 240 He deemed the ESA insufficient, because it did not establish that there is an injury by virtue of a violation. ${ }^{241}$ Although Akins reconfigured standing law in cases implicating so-called generalized grievances, the plaintiff's lack of election-related information sets that case apart from the citizen suit challenging government action on ideological grounds. But the Akins Court provided no guidance on where to draw the line between ideology and cognizable injury where the injury is widely shared. As a consequence, the scope of standing to sue under statutes that authorize the public to vindicate more abstract procedural injuries - such as the right to interagency consultation at issue in Lujan - remains ambiguous.

A statute that expressly draws the connection Justice Kennedy found lacking - the easiest case - should, like the FECA, trigger standing per se, or at least a presumption of standing that can only be rebutted with a clear showing of contrary congressional intent. But poorly worded legislation that invites lawyers to spin "injuries" from creative application of the myriad canons of statutory construction should be viewed with a jaundiced eye. After Akins, which turned primarily-if not exclusively - on the identification of statutory injury, the injury-infact prong of the Lujan test remains central in statutory standing cases, and must be carefully construed.

Causation and redressability is another matter. Although Lujan and its progeny conceive of all three prongs as equally vigorous under Article III, the Supreme Court has treated causation and redressability as dispensible in other public law cases, raising the question of whether they are meaningful in that context at all. In Utah v. Evans, ${ }^{242}$ the Court found that Utah had standing to challenge the legality of the 2000 Census counting method that caused it to lose a congressional representative. ${ }^{243}$ A recount would have required the Secretary of Commerce to issue a new set of numbers, the President to accept them, and the issuance of a new reapportionment statement to Congress. ${ }^{244}$ Pronouncing that " $[\mathrm{w}] \mathrm{e}$ read limitations on our jurisdiction to review narrowly," the Court found the alleged injury redressable because "[v]ictory would mean a declaration leading, or an injunction requiring, the Secretary [of Commerce] to substitute a new 'report' for an old one," which in turn

\footnotetext{
240. Lujan v. Defenders of Wildlife, 504 U.S. 555, 580 (1992) (Kennedy, J., concurring).

241. Id.

242. 536 U.S. 452 (2002).

243. Id. at 459-61.

244. See id. at 463 (declaring that a Utah victory would require a new census report).
} 
could lead to mechanical recalculations related to apportionment. ${ }^{245}$ Thus, "the courts would have ordered a change in a legal status (that of the 'report'), and the practical consequence of that change would amount to a significant increase in the likelihood that the plaintiff would obtain relief that directly redresses the injury suffered." 246 The Court cited Akins as an example of its having "found standing in similar circumstances." 247

Justice Scalia again dissented, charging the majority with committing "a flagrant violation of the separation of powers" 248 because redress depends on exercise of the President's discretion as well as that of "a majority of 435 Representatives and 100 Senators . . . whom federal courts are equally powerless to order to take official acts." ${ }^{249}$ Redress in Akins, he further reasoned, did not require action by a third party who could not be brought before a federal court and "for whom (as for the President) it would be disrespectful for us to presume a course of action."250 This awkward attempt to bring Akins within the Lujan framework only underscores their cases' incompatability, as redressability has never turned on whether the third party is or is not coercible or whether it "displays a gross disrespect" for courts to assume that it is. The Evans Court's cavalier redressability analysis demonstrates that, despite the perceived historical roots of a strict test for individualized injury, the Supreme Court has begun to recognize that Lujan does not readily fit every standing case.

Friends of the Earth, Inc. v. Laidlaw Environmental Services (TOC), Inc. ${ }^{251}$ is another striking example of a disintegrating redressability standard. In that case, the Court upheld environmental groups' statutory standing to bring suit against the holder of a pollution permit under the citizen-suit provision of the Clean Water Act $(\mathrm{CWA})^{252}$ based on the "quantum of deterrence" that the statute's civil penalties create, casting doubt on the vitality of the second and third prongs of the Lujan analysis. ${ }^{253}$ The Court concluded that, "[ $\left.\mathrm{t}\right] \mathrm{o}$ the extent [civil penalties]

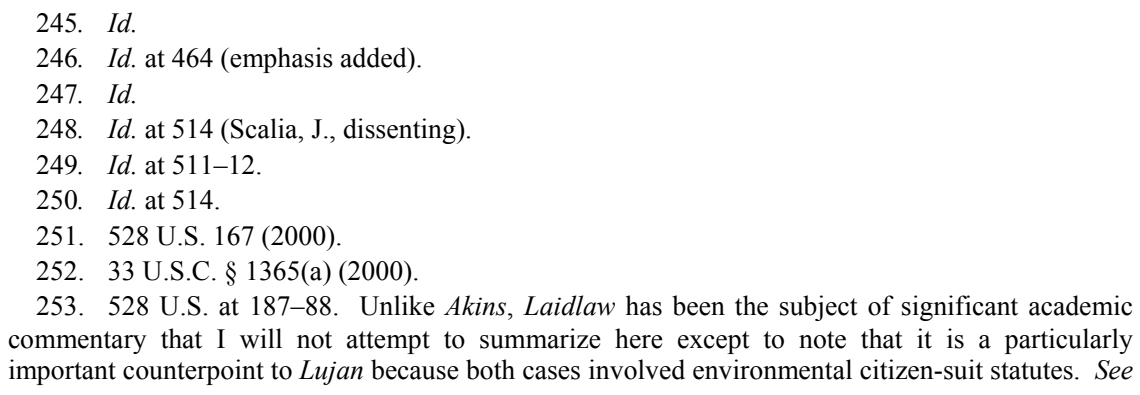


encourage defendants to discontinue current violations and deter them from committing future ones, the afford redress to citizen plaintiffs." 254 Recognizing the implications of such a trajectory for standing jurisprudence, Justice Scalia called the Court's weakened application of injury-in-fact in Laidlaw "a lever that will move the world," 255 as it "come[s] close to "mak[ing] the redressability requirement vanish"" and "place[s] the immense power of suing to enforce the public laws in private hands." 256 He charged in dissent that the Court's allowance of citizen suits for civil penalties under the CWA "has grave implications for democratic governance," and he challenged a standing model that would apply the redressability requirement merely to ensure that the plaintiff received some tangential benefit from a favorable judgment. ${ }^{257}$

A similar watering-down of Lujan standing - and a consequent shift towards an analysis of congressional intent in the public law contexthas appeared in lower-court decisions. In Hodges v. Abraham, ${ }^{258}$ for example, the Fourth Circuit blithely held that NEPA plaintiffs possess a procedural right to have the Executive observe procedures mandated by law "without meeting all the normal standards for redressability and immediacy." 259 In Ethyl Corp. v. EPA, ${ }^{260}$ a court found that a manufacturer of fuel additives had standing to sue the EPA to enforce the Clean Air Act's requirement of an "open procedure" for conducting environmental tests on an Akins-type injury theory. ${ }^{261}$ The plaintiff successfully argued that the information sought "might well help it develop and improve its products with an eye to conformity to emissions needs," agency essentially abide by the statute and establish test methods and procedures. $^{263}$ Recently, a U.S. district court in California found

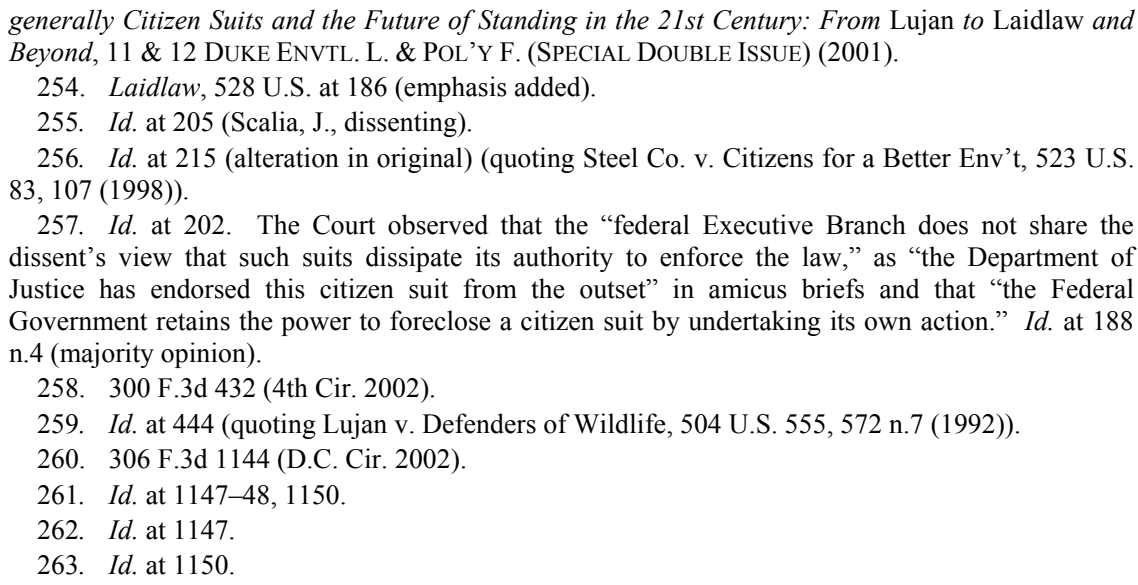


justiciable a suit under the Americans with Disabilities Act that challenged barriers to access that the plaintiff did not suffer himself. ${ }^{264}$ The court found standing based on an expert witness's inspection of the store in question during discovery on the theory that "Congress . . . stat[ed] that the purpose of the Act was to create a 'mandate for the elimination of discrimination' not just the weakening or reduction of discrimination which is what the case would be if plaintiffs were only allowed to bring suit for barriers that absolutely denied access." 265 The court dismissed causation and redressability concerns in a footnote as not having "been raised" and not "reasonably" worth raising. ${ }^{266}$

In part because the train has already left the station in terms of recognizing statutory standing in cases involving something less than redressable particularized injury, a forthright recasting of the Lujan standard in public law cases is becoming increasingly necessary. As the FEC has specifically argued in attempting to dispel the obvious reach of Akins, Lujan is so entrenched in the psyche of justiciability jurisprudence that it seems "radical" to challenge it at all. ${ }^{267}$ Courts should, however, as a threshold matter read Akins as expressly disavowing the causation and redressability prongs of the traditional test for administrative cases, where they have little content, and look primarily to whether Congress created a nonabstract "injury"- by, for example, conferring a right to information —-within the meaning of Akins. ${ }^{268}$

After all, agencies on remand are not constrained to a particular substantive outcome. In revisiting the facts and the law under judicial guidelines, an agency may arrive at a perfectly lawful decision that leaves the initial injury unredressed. Courts have therefore recognized that causation is satisfied "when a plaintiff demonstrates that the challenged agency action authorizes the conduct that allegedly caused the plaintiff's injuries, if that conduct would allegedly be illegal otherwise." 269 In cases involving regulation of a third party, Lujan causation is almost never present because the link between the

\footnotetext{
264. Wilson v. Pier 1 Imports (US), Inc., 413 F. Supp. 2d 1130, 1135 (E.D. Cal. 2006).

265. Id. at 1133 (quoting 42 U.S.C. $\S 12101(\mathrm{~b})(1)(2000)$ ). The court also discussed the split among district courts on this issue. Id. at 1132-35.

266. Id. at $1132 \mathrm{n} .3$.

267. See supra note 116 and accompanying text.

268. See Wyo. Outdoor Council v. U.S. Forest Serv., 165 F.3d 43, 51 (D.C. Cir. 1999) (indicating that in procedural rights cases the "necessary showing" supporting the "constitutional minima of injury-in-fact, causation, and redressability ... is reduced").

269. See Animal Legal Def. Fund, Inc. v. Glickman, 154 F.3d 426, 440 (D.C. Cir. 1998) (en banc) (emphasis added) (upholding standing in facial challenge to regulations allegedly authorizing statutorily proscribed inhumane treatment of animals).
} 
government activity and the claimed injury is necessarily tenuous insofar as it is contingent on nonparties' behavior. Akins fully embraced this inevitability.

The rise of the administrative state no doubt contributes to the LujanAkins dilemma over causation and redressability, because it naturally occasions an increase in litigation to enforce public values. In his Lujan concurrence, Justice Kennedy observed that as "Government programs and policies become more complex and farreaching, ... [m]odern litigation has progressed far from the paradigm of Marbury suing Madison to get his commission." 270 Increased legislation and the expansion of the powers of the Executive Branch naturally prompt litigation to enforce statutory mandates. ${ }^{271}$ Such litigation is arguably the very litigation to enforce public values that Lujan rejects. But it is also unavoidable, which is perhaps why-notwithstanding Lujan-courts have not strictly applied the causation and redressability requirements in a number of administrative cases. ${ }^{272}$

Akins represents a more modern conception of standing that is attuned to the realities of administrative litigation. The injury-in-fact test was designed to restrict individuals' ability to sue to enforce the legal duties of agencies with greatly augmented powers. Given the nature of common law claims, it is unsurprising that the test is apt to favor the regulated - who are readily able to demonstrate particularized injuryover the individual who as a member of the public is a beneficiary of the law. ${ }^{273}$ The position that statutory beneficiaries have standing to sue to implement a law only if they too can demonstrate injury that is direct and particularized and thus akin to that suffered by a regulated party is suspect. If one accepts the constitutionality of the delegation of

270. Lujan v. Defenders of Wildlife, 504 U.S. 555, 580 (1992) (Kennedy, J., concurring) (citing Marbury v. Madison, 5 U.S. (1 Cranch) 137 (1803)).

271. See Sunstein, supra note 5, at 179 (explaining that the current standing doctrine developed "as part and parcel of the heated struggle, in the 1920s and the 1930s, within the country and the courts about the constitutional legitimacy of the emerging regulatory state").

272. In a remarkable footnote, Justice Scalia conceded in Lujan that "one living adjacent to the site for proposed construction of a federally licensed dam has standing to challenge the licensing agency's failure to prepare an environmental impact statement, even though he cannot establish with any certainty that the statement will cause the license to be withheld or altered" but that people living at the other end of the country would not. 504 U.S. at 572 n.7. Even under Lujan itself, therefore, the causation and redressability requirements wiggle.

273. The test has been challenged as having a disproportionately negative impact on the poor and disenfranchised. See, e.g., Nichol, supra note 59, at 333 ("Anomalously, the power to trigger judicial review is afforded most readily to those who have traditionally enjoyed the greatest access to the processes of democratic government. . . Minority plaintiffs, poor litigants, unwed mothers, black prisoners, and indigent patients get the harshest treatment in injury law."). 
Executive power to agencies, ${ }^{274}$ the realities of the administrative state require a more practical standing analysis in citizen suits against the federal government.

While the permutations of extending Akins's premises to other citizen-suit statutes can only be revealed slowly through lower-court decisions, judicial acknowledgement that Akins repudiated Lujan and established injury per se in cases seeking information under the FECA is an important first step in bringing order to this dizzying area of the law, and may be inevitable as a natural consequence of the expansion of the modern administrative state. Rather than purporting to apply Lujan in a context where it does not fit, courts should distinguish Lujan and adopt an approach that squarely acknowledges that the public law model of adjudication has a legitimate place in public law litigation.

\section{B. Administrative Litigation and Substantive Review: Two Bites at the Article II Apple?}

The foregoing subpart attempts to make the case for treating FECA plaintiffs seeking election-related information as establishing standing per se, and for recognizing that Akins and later cases have marginalized the causation and redressability requirements in such a way as to render them less meaningful in broader public law contexts. The counterargument that would denounce increased access to the courtsand urge reversion to Lujan in FECA cases - is really about Article II, not Article III. The Take Care Clause grants the President the exclusive authority to "faithfully execute[]" federal law as enacted. ${ }^{275}$ As Professor Sunstein has observed, "[i]t is for this reason that the standard administrative law case raises no issue under the Take Care Clause. If an object of regulation establishes that an agency has enforced the law in an unlawful way, the President has violated his duty under the Take Care Clause." ${ }^{276}$ Courts can constitutionally adjudicate such a dispute. Although the Supreme Court has already established that a citizen cannot invoke the judiciary to compel most agency enforcement activity, ${ }^{277}$ standing to sue an agency should not be construed in a way that nullifies congressional directives and leaves the Executive Branch free to disregard the law.

274. See TRIBE, supra note 81 , at 131 (discussing constitutionality of the administrative state).

275. U.S. CONST. art. II, § 3.

276. Sunstein, supra note 5, at 212.

277. See supra note 93 and accompanying text. 
The separation-of-powers concerns underlying Lujan, although legitimate, are addressed elsewhere in the administrative review process. Plaintiffs suing a federal government agency under the generic review provisions of the Administrative Procedure Act (APA) ${ }^{278}$ must, of course, satisfy Article III standing in every case. Those who can demonstrate injury-in-fact sufficient to distinguish themselves from someone who sues as the people's representative avenging a so-called "generalized grievance" find themselves faced with very deferential substantive standards for obtaining review of agency inaction under the APA. A bald claim that the agency is not doing its job will survive neither a motion to dismiss for lack of standing nor a motion for summary judgment on the merits for substantially similar reasons. As a consequence, the relationship between standing to sue a federal agency for vindication of procedural rights and the standards for securing substantive review of agency action support an interpretation of Akins that enables interested parties to bring challenges to government nonenforcement decisions under an appropriately worded citizen-suit statute, while continuing to afford agencies the deference they already enjoy under the APA.

The Supreme Court's APA jurisprudence reflects movement from a default standard of reviewability ${ }^{279}$ toward one of unreviewability in cases involving agency refusals to enforce. The Court held in Heckler v. Chaney $^{280}$ that if Congress has not established standards for review of agency activity, the courts are without jurisdiction to review the action for the same reasons that a court, applying Lujan, could dismiss on standing grounds: arbitrariness challenges to the Executive are for the political branches, not the courts. ${ }^{281}$ In Norton v. Southern Utah Wilderness Alliance, ${ }^{282}$ the Court deemed agency inactivity largely unreviewable under $\S 706(1)$ of the APA, which sets forth a cause of action to "compel agency action unlawfully withheld or unreasonably delayed," ${ }^{283}$ because courts can only compel agencies to take discrete

278. 5 U.S.C. $\$ \S 701-706(2000)$.

279. See Steenholdt v. FAA, 314 F.3d 633, 638 (D.C. Cir. 2003) (citing Abbott Labs. v. Gardner, 387 U.S. 136, 140 (1967)) (setting forth general rule of reviewability under the APA); Sierra Club v. Yeutter, 911 F.2d 1405, 1410 (10th Cir. 1990) (citing Abbott Labs., 387 U.S. at 140) ("As a general matter, all agency action is presumed reviewable.").

280. 470 U.S. 821 (1985).

281. See id. at 830-32 (holding that agency decisions regarding whether to take enforcement action are presumptively unreviewable, because there is "no law to apply" under the "committed to agency discretion" exception to APA review).

282. 542 U.S. 55 (2004).

283. 5 U.S.C. $\S 706(1)$ 
actions under the APA; broad programmatic attacks on agency action are for the political process to resolve. ${ }^{284}$ For its part, the FECA provides no mechanism by which a third party may obtain judicial review of the FEC's enforcement decisions after an investigation has been conducted. $^{285}$ All that can be achieved by invoking the citizen-suit provision is an order requiring the agency to take the next investigative step. ${ }^{286}$

Although the FECA's private right of action does impinge on agency discretion to direct resources away from the investigative process in certain cases, because of the statute's limited scope, the argument for rigorous standing analyses in $\S 437 \mathrm{~g}(\mathrm{a})(8)$ suits is not compelling. More pragmatic are the implications of a per se informational standing analysis under Akins. A careful look at the D.C. Circuit's opinion in CREWv. $F E C^{287}$ is illustrative. Although the complaint was ultimately dismissed for lack of standing, the holding turned in part on the court's notation that that CREW "agree[d] with the Commission's reason-to-believe determinations and expresse[d] satisfaction that it received 'a publicly disclosed ruling that the administrative respondents violated the law.",288 In other words, Judge Randolph wrote, "we do not know what legal principle CREW thinks the Commission . . . violated." 289 Or as the district court put it, "CREW has received all or more than it is due under FECA," including the FEC's assessment of the list's value (zero), and that there was no requirement under the FECA that "the FEC . . . value an in-kind contribution in the form of a contact list." 290 Thus, the court dismissed the complaint in part because CREW's claim on the merits was fatally flawed. The FEC's exercise of its prosecutorial discretion in

284. Norton, 542 U.S. at 64. See generally Bressman, supra note 59 (discussing arbitrariness approach to judicial review of agency inaction).

285. See Perot v. FEC, 97 F.3d 553, 558 n.2 (D.C. Cir. 1996) (“Apart from $\S 437 \mathrm{~g}(\mathrm{a})(8)(\mathrm{C})$, there is no private right of action to enforce FECA against an alleged violator."); $c f$. Republican Nat'l Comm. v. FEC, 76 F.3d 400, 404 (D.C. Cir. 1996) (applying Chevron deference to FEC regulation).

286. Under $\S 437 \mathrm{~g}(\mathrm{a})(8)(\mathrm{c})$, the complainant may bring a civil action to remedy the violation alleged in the original complaint if the Commission fails to conform to the district court's declaration that the dismissal of the administrative complaint was contrary to law. 2 U.S.C. $\S$ $437 \mathrm{~g}(\mathrm{a})(8)(\mathrm{C})(2000)$. The district court reviews the propriety of the dismissal under a deferential standard that considers whether the FEC's construction of a statute is sufficiently reasonable to be accepted by a reviewing court. FEC v. Democratic Senatorial Campaign Comm., 454 U.S. 27, 37, 39 (1981).

287. 475 F.3d 337 (D.C. Cir. 2007); see also supra notes 124-42 and accompanying text (discussing the facts and holding of $C R E W$ ).

288. CREW, 475 F.3d at 340 (quoting Br. for Appellant 22).

289. Id.

290. Citizens for Responsibility \& Ethics in Wash. [CREW] v. FEC, 401 F. Supp. 2d 115, 121 n. 2 (D.D.C. 2005), aff'd, 475 F.3d 337. 
letting this violation go, although politically troublesome to CREW, was not unlawful. Moreover, unlike in Kean, the FEC had undertaken the investigation on its own accord, which resulted in the disclosure of a great deal of information to the public, including the fact "that an illegal in-kind contribution took place," "that the in-kind contribution was a master contact list containing the names and contact information of conservative activists," "that the list's monetary value [was] negligible," and "the identities of the individuals and campaign involved in the illegal transaction.",291

Had the FEC refused to conduct the initial investigation, however, none of this information would have been made public. Under an informational standing analysis identical to that undertaken by the D.C. Circuit, ${ }^{292}$ it would have lacked jurisdiction to review a complaint by CREW challenging the dismissal of the administrative complaint preinvestigation on causation and redresssability grounds. Such a ruling would clearly be incorrect under Akins. Ultimately, perhaps, the court's decision to deny standing had much to do with the fact that the FEC had satisfied its legal obligations and CREW had obtained all the information it reasonably needed. Had the court applied Akins to find standing and resolved the claim on the merits, the standing analysis would be less prone to the subjective manipulation Lujan critics decry. ${ }^{293}$

Yet Article III should not be interpreted so flexibly that courts are thrust into the center of the political arena. The limited role of the judiciary in our system of government forecloses a justiciability doctrine that would render cognizable all generalized claims seeking intangible public benefits, a scenario that would undermine - if not eliminate - the separation of powers. Some inquiry is necessary to ascertain whether this plaintiff is mired in a case or controversy against the government that warrants judicial attention. Although the injury-in-fact test has served the crude function of narrowing the range of litigants - thus the kinds of public law cases - that federal courts adjudicate, its purported intolerance for any judicial review to enforce public values is simply out of step with the realities of modern administrative law, and is not explicitly mandated by Article III in any event. It dramatizes Article II concerns that are separately addressed in the review provisions under the APA, as construed by the Supreme Court. ${ }^{294}$

291. Id. at 121.

292. See supra notes 124-37.

293. Cf. Fletcher, supra note 62, at 223 (arguing that "standing should simply be a question on the merits of plaintiff's claim").

294. See supra note 278 and accompanying text (discussing judicial interpretation of the APA). 
To be sure, Akins and Lujan crossed swords on the basic question of congressional power to confer standing by defining an interest-and conversely, an injury - by statute. Justice Scalia deemed it "obvious" in Lujan that

[t]o permit Congress to convert the undifferentiated public interest in executive officers' compliance with the law into an "individual right" vindicable in the courts is to permit Congress to transfer from the President to the courts the Chief Executive's most important constitutional duty, to "take Care that the Laws be faithfully executed." 295

But citizen-suit statutes such as the FECA, along with the APA, ${ }^{296}$ each represent a determination by Congress to enhance a particular public value, and thus a collective public acceptance of the interest the legislation protects. ${ }^{297}$ The FECA's judicial review provisions similarly manifest congressional choice regarding the best way to implement a statute and ensure agency accountability for failure to enforce the FECA's disclosure requirements. An elected Congress may better represent democratic will than agency heads and administrators who are politically accountable only indirectly (through the control of an elected President). Its citizen-suit legislation by its very nature contemplates separation-of-powers concerns. Standing notwithstanding, the modest infringement of agency discretion under the FECA's citizen-suit provision does not justify its nullification on separation-of-powers grounds under the auspices of Article III justiciability.

\section{CONCLUSION}

A test for Article III standing devoid of arbitrariness is an oxymoron. But arbitrariness is not confusion and obfuscation. The Akins Court's failure to make clear that it was departing from Lujan in its analysis of causation and redressability has made it difficult for citizen-standing jurisprudence to develop with clarity and direction. Whether Akins is the better view depends in part on whether other checks on overzealous judicial review of Executive action suffice. The myriad critiques of the FEC and the circumscribed applicability of the FECA's citizen-suit provision suggest that Congress acted reasonably in determining that

295. Lujan v. Defenders of Wildlife, 504 U.S. 555, 577 (1992) (quoting U.S. ConST. art. II, § 3).

296. 5 U.S.C. $\S \S 701-706$ (2000).

297. See Nichol, supra note 20, at 1947 ("Legislative enactment reflects shared acceptance of the interest and typically alleviates any concern over separation of powers."). 
there is a role for the judiciary in ensuring the statute's enforcement. That role must be carefully circumscribed, but the congressional determination that Executive checks on unelected agency officials' conduct do not suffice to ensure implementation of the law in certain contexts is not expressly prohibited by the Constitution. The question remaining is how far is too far in evaluating Congress's exercise of its authority to legislate standing and what criteria should inform the answer.

As a first step, this Article seeks to recapture Akins's main contribution to standing jurisprudence, which is often lost. Akins, properly construed, sets forth a rule of law that is refreshingly resistant to line-drawing. The lack of subjectivity is what most distinguishes Akins's standard for informational injury from Lujan's injury-in-fact test. ${ }^{298}$ Akins also dilutes particularized injury, causation and redressability in ways that cut across many administrative actions. If Congress creates a right to information, plaintiffs can sue an agency to obtain that information, even if the citizenry at large shares the plaintiff's injury and even if ultimate redress depends both on the exercise of agency discretion and the actions of third parties that are not named in the lawsuit. Courts should squarely apply Akins to FECA cases seeking information and take steps to dissuade the FEC from pursuing a strategy of challenging Akins standing under all circumstances.

Because the merits of administrative challenges to Executive refusals to enforce are governed by highly deferential standards of review, the separation-of-powers concerns underlying the Lujan test are adequately addressed by the more forgiving Akins inquiry in citizen-suit cases brought to prompt enforcement action. Its proper application would avoid cumbersome litigation over particularized injury-litigation that can keep worthy plaintiffs from having their day in court based on idiosyncratic factual analysis-while protecting against citizen lawsuits that attempt to second-guess Executive activity in contravention of Article II. 